\title{
DAS RELIGIÕES PRIMEVAS ÀS MODERNAS. INFLUÊNCIA NOS ORDENAMENTOS JURÍDICOS ATUAIS ${ }^{1}$
}

FROM PRIMITIVE TO MODERN RELIGIONS. INFLUENCE IN THE CURRENT LEGAL SYSTEMS

Antonio Augusto Machado de Campos Neto*

"Deus está presente em todas as Religiões; outras crenças são tão válidas como o Hinduísmo"

Ramakrishna (sábio hindu, 1836-1886)

"Quem não sofre, não aprende a lutar"

Maria João de Deus (mãe de Chico Xavier)

"O Espiritismo repousa menos no maravilhoso e no sobrenatural do que a própria Religião. Os que o atacam nesse sentido não o conhecem e, mesmo que fossem os maiores sábios, nós lhe diríamos: 'se a vossa Ciência que vos ensinou tantas coisas, não vos revelou que o domínio da Natureza é infinito, sois apenas meio-sábios.'."

Allan Kardec

"Ao invés de olhar para baixo, olhe para cima; às estrelas, ao Universo"

Stephen Hawking

Resumo:

A Religião pode influenciar quase tudo em nossas vidas, desde as antigas cavernas ao lar moderno que moramos, alimentos que consumimos, rituais de casamento e morte até usos e costumes de tribunais e governos, molda crenças, códigos morais e identidade nacional: cidadãos e Nações descrevem a si próprios em termos religiosos; cristãos e judeus, hindus e muçulmanos, xintoístas ou budistas. Desde a Religião Primeva às modernas, proporciona às pessoas esperança no futuro e conforto no desespero; oferece motivo ao trabalho beneficente, é fonte de inspiração artística e constitui centro social para muitos. Conflitos religiosos têm causado dor e morte ... mas a Religião também é a base de muitos movimentos pacíficos. As Religiões Primevas desempenham parte fundamental na vida de muitos indivíduos

1 Este artigo é dedicado à Ana Rita Alves Meneses Lima, ex-chefe da Seção de Edição da Revista e Outros Periódicos da FDUSP e por onze anos assessora do Autor no Serviço Técnico de Imprensa, desta Academia de Direito.

* Bacharel em Direito pela Faculdade de Direito da Universidade de São Paulo (1973). Bacharel em Jornalismo pela Faculdade de Comunicação Social Cásper Líbero (1976). Ex-Chefe do Serviço Técnico de Imprensa e Propaganda da Faculdade de Direito da Universidade de São Paulo. 
em épocas modernas como os aborígenes australianos, índios das Américas, tribos africanas e população das ilhas do Pacífico; são correntes religiosas antigas praticadas nas primeiras civilizações do Mediterrâneo e do Oriente Médio, nas culturas escandinavas e celtas do Norte da Europa, povos que cultuavam deuses, a maioria dos quais controlava parte determinada do Universo como o Sol, a Lua, as estrelas, os oceanos e montanhas ou, ainda, áreas da vida humana como o amor, a guerra e a Agricultura. $\mathrm{O}$ foco do artigo é o de analisar, a partir de nossos ancestrais, influência nas origens da Humanidade em legado de extraordinárias lendas e mitos, base de futuras sociedades notórias pelo passado. Das Religiões politeístas às monoteístas - Judaísmo/Cristianismo/Islamismo; delas, se extraem trajetos da constituição de diplomas jurídicos que remontam a História da Civilização, da Religião e do Direito.

Palavras-chave: Religião Primeva. Religião Revelada. Influência nos principais ordenamentos jurídicos. Judaísmo. Cristianismo. Islamismo. Hinduísmo. Budismo. Confucionismo. Taoismo. Xintoísmo. Espiritismo.

\begin{abstract}
:
Religion can influence almost everything in our lives, from the ancient caves to the modern home we live in, food we eat, rituals of marriage and death to the customs and customs of courts and governments, shapes beliefs, moral codes, and national identity: citizens and nations describe themselves in religious terms; Christians and Jews, Hindus and Muslims, Shinto or Buddhists. From Primeva to modern religion, it gives people hope in the future and comfort in despair; offers a reason for charitable work, is a source of artistic inspiration and is a social center for many. Religious conflicts have caused pain and death ... but Religion is also the basis of many peaceful movements. The Primeval Religions play a fundamental part in the lives of many individuals in modern times such as Australian aborigines, Indians of the Americas, African tribes and population of the Pacific islands are ancient religious currents practiced in the early Mediterranean and Middle Eastern civilizations, in the Scandinavian and Celtic cultures of Northern Europe, god-worshiping peoples, most of whom controlled a determinate part of the Universe such as the Sun, Moon, Stars, oceans and mountains or even areas of human life such as love, war and agriculture. The focus of the paper is to analyze, from our ancestors, the influence in the origins of mankind in legacy of extraordinary legends and myths, base of future societies notorious for the past. From Polytheistic Religions to Monotheists - Judaism / Christianity / Islam; of them, are extracted routes of the constitution of laws that go back to the History of Civilization, Religion and Law.
\end{abstract}

Keywords: Religion Primeva. Revealed Religion. Influence in the main legal systems. Judaism. Christianity. Islam. Hinduism. Buddhism. Confucianism. Taoism. Shinto Spiritism. 
I. Das Religiões Primevas às Modernas

1. Introdução

Dentre as virtudes do ser humano, a Fé em grupos espalhados por todo o planeta indiscutivelmente é a mais significativa. Desde a formação do planeta, nossos ancestrais acreditavam em um Ser Supremo; enfatiza-se a credulidade divina na estrela de quinta grandeza: o Sol. A Religião tem o desempenho maior no relacionamento humano com o Divino, além de auxiliar a se manipular os mistérios da vida, incluso o estágio pósmortem. Em tempos atuais, tem existido declínio na crença e na observância religiosa, lembrando países desenvolvidos da sociedade ocidental se travestindo gradativamente aos valores materiais, extirpando, assim, o lado espiritual.

As Igrejas cristãs têm registro no aumento de frequência de fiéis em cerimônias religiosas, a missa, estatística bem-vinda ao futuro da Humanidade. Por outro lado, Islamismo e Budismo se expandem notadamente nos Estados do Oriente Médio. As Religiões podem ser catalogadas em consonância às regiões do Mundo, das quais se originaram.

As Religiões indianas - Hinduísmo, Budismo, Jainismo - compartilham a ideia de que a existência da vida constitui ciclo contínuo de nascimento, morte e renascimento, do qual o homem religioso procura se libertar. As Religiões chinesas e japonesas têm crença em algo comum, isto é, reverenciar os Espíritos de ancestrais mortos. Nas Religiões monoteístas - Judaísmo, Cristianismo, Islamismo - a crença em Deus Único, o conceito da Revelação e o papel desempenhado pelos profetas e textos sagrados: características comuns da sua formação.

Por fim, nas Religiões Primitivas ou Primevas a crença de que os Espíritos habitam aspectos da Natureza, locais da prática de rituais religiosos relacionados a eles como a de promover a fertilidade.

A essência da História consta de coletânea de fatos surgidos para serem lembrados que pertencem a todos nós e quando uma Religião se identifica intimamente com determinada Nação ou mesmo pequeno grupo, conflitos podem surgir. Verifica-se que a intolerância religiosa, quase sempre mesclada às questões políticas e puro terrorismo, tem sido motivo de desavenças, por meio da própria História, quando conflitos religiosos podem crescer e desencadear guerra de grande proporção. $\mathrm{O}$ fato é notório quando o zelo missionário é mal-orientado, isto é, grupos que consideram a sua Religião superior a todas as outras, levando a conversões forçadas de inocentes, conquistas desastrosas e derramamento de sangue. Infelizmente a premissa de que a Religião auxilia... mas também mata! 
A Religião propriamente dita normalmente é responsabilizada pelos conflitos que acontecem na História da Humanidade; todavia, a maioria dos textos sagrados de líderes religiosos e seus seguidores ensina o valor do entendimento junto à compaixão e respeito ao próximo, por meio de liderança correta - respaldada no Catolicismo pelo Papa Mario Jorge Bergoglio (Francisco), o primeiro Papa jesuíta da História da Religião -, favorece a compreensão e o auxílio à solução do equacionamento das diferenças na Fé, de cada cidadão.

Exemplos de líderes religiosos da História contemporânea: empregaram a Fé no intuito de maior entendimento como, também, tolerância, aos moldes de Desmond Tutu, ativista atuante na campanha contra o sistema de apartheid, na África do Sul. O dalai-lama exilado de sua terra natal, o Tibete, lidera os tibetanos, por meio de sua virtude maior: a compaixão. E muitos outros menos famosos trabalham pela paz em lugares afetados por distúrbios, contribuindo com instituições de plena caridade e organização de ajuda exclusiva para sanar danos causados por estúpidas guerras. Vale a pena registrar o desempenho do cardeal dom Evaristo Arns, indicado ao Prêmio Nobel da Paz em 1989, protetor dos moradores de rua, acolhendo-os em Casa de Caridade criada por ele; na luta da Igreja católica contra a ditadura militar nos anos 1960/70 a 1985. Defensor dos Direitos Humanos, jornalista e coordenador na busca de desaparecidos no âmbito internacional, exemplo dos jovens argentinos encontrados no Chile, durante a repressão naquele país vizinho, em 1980, configurando respeito à validade e valoração da Declaração Universal dos Direitos Humanos, de 1948.

Em apreciação pessoal, Médicos Sem Fronteira composta por médicos, assistentes sociais, enfermeiros voluntários; se trata de organização indubitavelmente compromissada ao socorro dos seres humanos necessitados de tratamento médico, enfatizando assistência oferecida às crianças carentes e adoecidas africanas. O destino, às vezes, é implacável; não há retorno, não muda e seres humanos - normalmente pobres e humildes - são obrigados a sair de suas terras, casas e raízes, classificados hodiernamente "os refugiados"; dentre suas virtudes, a coragem em pedir ajuda à Humanidade, seres humanos como eles.

As guerras acarretam miséria e fome (a exceção se aplica ao Império romano, porque aos romanos a guerra era altamente lucrativa); embora não sejam conhecidos seus exemplos mostram como a Religião pode realizar diferenças tanto na vida diária quanto na espiritual. Registro, por último - nos anos 70 -, o sociólogo Hebert de Souza, apelido "Betinho", na Campanha contra a Fome que assolava o Estado brasileiro. O desprezo pelo Governo Federal carecia na época.

Certas Religiões têm estrutura formal altamente organizada por meio de hierarquia de lideranças na transmissão de instruções, sendo evidência maior a Igreja Católica Apostólica Romana: Papa, bispos e sacerdotes. Outras, como a xiita islâmica 
têm instituições semelhantes, embora sem hierarquia, uma vez líderes - sacerdotes mais velhos - orientados ao ensino geral desde o espiritual à conduta social diária.

As Religiões organizadas são basicamente sociais; instituições que possibilitam aos indivíduos a prática do culto, grupos reunidos, criando laços que atendam interesses e necessidades especiais. Acrescenta-se que, este comportamento, ajuda criar senso de comunidade: o retorno aos nossos ancestrais!

Neste tópico, cumpre salientar que as Religiões têm ritual cerimonial realizado quase sempre de determinada forma, assim como eventos religiosos, desde o culto regular até as peregrinações realizadas, pelo menos em única vez, incluem o ritual. Normalmente o ritual envolve determinada ação corporal específica como, por exemplo, ajoelhar-se ao rezar, caminhar ao redor de templo sagrado, venerar a imagem de um deus ou deusa, dançar fantasiado ou, ainda, se sentar em posição especial, durante a meditação. Além disso, rituais conhecidos, a reza ou oração, são ligados a formas regulares de culto; geralmente em determinados dias ocorridos em recinto religioso conduzidos por autoridade religiosa, padre, rabino ou imã.

Os ritos de passagem marcam transição de período da vida para outro como o post-mortem; acontecem após o nascimento, em seguida, na puberdade ou, ainda, quando o indivíduo se torna membro de Religião escolhida, pessoalmente, no casamento e após a morte (missa de corpo presente/sétimo dia). Por outro lado, rituais festivos são realizados em dias ou semanas relevantes, em consonância ao calendário religioso que podem, por sua vez, ocorrer em datas associadas ao fundador da Religião: profetas ou personagens importantes. Enfim, outros rituais, especialmente valorizados em Religiões Primevas, incluem cerimônias de cura que são ritos que trazem proteção aos cidadãos e sua comunidade. Exemplo, exorcismos e práticas que auxiliam a prever o futuro, por meio dos visionários.

Recorda-se importante ritual do Zoroastrismo, de Zaratustra ou Zoroastro: o jashan, cerimônia de ação de graças. A realização de um jashan favorecia o bem-estar tanto no mundo físico quanto no espiritual e os objetos usados atuavam como símbolos dos imortais, sendo o principal o Ahura Mazda, fonte de luz e bondade que, por sua vez, é representado pela queima de sândalo. O Zoroastrismo é a primeira Religião da História da Humanidade a praticar a crença em um Deus Único.

Algumas Religiões menores são assim classificadas, mas, na verdade, tratam-se de sociedades secretas que ainda existem como a Irmandade de Sangue ("Le Sang”) no Sul da Espanha e da França ou o Priorado do Sião. A primeira, apresenta ritos, por meio de eventuais desfiles noturnos, quando seus membros vestem enormes capuzes - por não poder serem identificados -, munidos de tochas e gigantescas estátuas cristãs em clima sombrio de se assistir; têm o hábito de autoflagelação, no intuito de recordar as dores sentidas por Jesus Cristo. O trunfo dessa sociedade secreta aborda a guarda de 
relicário nunca comprovado: a existência do corpo embalsamado de mais de 2 mil anos de Jesus Cristo.

O Priorado de Sião é uma sociedade cristã europeia - fundada em 1099 -, existe de fato e totalmente fechada em seus membros e, em 1975, a Biblioteca Nacional de Paris descobriu diversos pergaminhos que passaram a ser conhecidos como Os Dossiês Secretos, os quais identificam inúmeros de seus participantes; neles, nomes como Isaac Newton, Botticelli, Victor Hugo e Leonardo da Vinci. Há registros de que o início da sociedade tenha se realizado na cidade de Rêné-de-Châmps, Sul da França, onde o padre da Igreja local encontrara valioso tesouro, munindo o recinto religioso com imagens sacras cobertas de puro ouro; mas também auxiliado a comunidade pobre local. Os registros apontam, também, ser o endereço religioso das tumbas de Maria Madalena e de Jesus Cristo, nunca comprovados.

Em 1118, nove cavaleiros chegaram à Jerusalém e assumiram para si o papel de protetores ostensivos aos peregrinos dos ladrões do deserto, quando o Rei Balduíno II os acolheu, alojando-os no Monte do Templo, local conhecido na época por Estábulo de Salomão. Essa informação é de vital importância, porque exatamente era o que faziam, obtendo nesta proteção a participação do influente Bernardo de Clairvaux, ou Claraval, período em que a Ordem Templária fora reconhecida pelo Vaticano e, formalmente, como Ordem dos Pobres Cavaleiros de Cristo e do Templo de Salomão, tinham obediência exclusiva ao Papa e desobrigados a pagar impostos a nenhum Governo secular ou mesmo Igreja oficial; na época, enorme vantagem para a Ordem. São considerados fundadores do primeiro Banco financeiro da História da Humanidade e da posse do Santo Graal - que não é apenas o cálice de Cristo: é muito mais -, levado pelos templários à Região norteamericana, em ilha repleta de carvalhos, identificada posteriormente Oak Island, antes da descoberta de Cristóvão Colombo. Documentos antigos franceses afirmam que entre 1178 e 1180, os templários chegaram à ilha assinalada.

Em 1717, a Maçonaria, considerada a mais ampla e poderosa sociedade secreta do Mundo. Surgida na Idade Média, suas crenças pregam história bem mais antiga, amparada em fundamentos filosóficos ao crescimento das Religiões Primevas. A Maçonaria acabou se transformando em seleto grupo de indivíduos eminentes em vários setores da sociedade medieval ... e da moderna, trabalham à sombra porque existe Bula papal censurando-a e considerando-os hereges; dentre as alegações a de que seus membros consideram a figura do Papa personificação do Diabo, o que não é verdade. Historiadores maçons traçam o início da Irmandade a vários pontos da História da Religião; alguns, alegam que Adão era maçom e a tese mais aceita entre eles determina que os descendentes de Noé foram um tipo de maçons ancestrais, uma vez acreditarem, como os hebreus, em um Único Deus e na imortalidade da Alma. "Maçom", do idioma francês, significa "pedreiro" e de fato grupo seleto que construía castelos e igrejas com tijolos e 
argamassa, de posição privilegiada e autônoma dentro dos Reinos, além de Poder, pois eram apadrinhados por Reis e pelo Clero. Ainda, segundo a crença maçom, os herdeiros de Noé (o da Arca) se misturaram com diversos outros povos na Torre de Babel; quando ela desabou os preceitos da Irmandade, chamados de "mistérios", se espalharam para diversas outras Religiões Primevas, que passaram a praticar a "maçonaria espúria"; os hebreus continuaram com a "maçonaria pura". O número 33 é referência da Maçonaria; o número um é o do aprendiz e o trigésimo terceiro, o do soberano grão inspetor-geral. Os símbolos são significativos como o "olho que vê tudo" no interior de triângulo, o esquadro, prumo e nível indicam a retidão moral, a retidão de conduta e a igualdade de condições naturais entre os homens, respectivamente; o compasso simboliza o dever do maçom perante a si mesmo: o de assimilar suas paixões e motivos dentro dos limites, a caveira e o caixão servem como lembrança constante da mortalidade ("memento mori") e o ramo de acácia, a imortalidade da Alma, um dos principais preceitos da Ordem. As sedes são chamadas de Lojas, organização iniciada no século XVIII e no século XIX, duas Grandes Lojas europeias viraram referência: a Grande Oriente da França e a Grande Loja Unida da Inglaterra. Nas Américas, a Maçonaria integra o México, Argentina e Uruguai ... na busca da Sabedoria!

A Opus Dei é uma organização católica profundamente conservadora e de recursos financeiros extraordinários, existe de fato e prelazia do Vaticano; em 2004 aproximadamente vinha sendo objeto de controvérsias, devido relatos de lavagem cerebral, coerção e prática perigosa conhecida como "mortificação corporal".

Por último, a Ordem Rosacruz, grupo místico e filosófico espalhado por todo o planeta que tem como objetivo o de ensinar os seus membros sobre os mistérios do Mundo e sobre si próprios; assim como a Igreja católica tem paróquias com diversos nomes e estilos, existem várias ordens e fraternidades Rosacruzes, que podem diferir entre si na forma e essência de ensinar. Mas todas têm o mesmo propósito: continuar o trabalho de Christian Rosenkreuz, monge alemão que teria vivido no século XIV e fundado a primeira Ordem na Europa, no intuito de divulgar o que aprendeu com mestres muçulmanos sobre artes ocultas. A antiga e mística Ordem Rosacruz, Amorc, uma das maiores do Mundo, afirma que a prática das artes ocultas oferece benefícios desde o nível físico com técnicas específicas para reduzir o estresse e ampliar processos de cura até os níveis mentais e espirituais, por meio de técnicas que despertam a consciência objetiva, o subconsciente, o id da Psicologia e a relação de cada ser com o "Todo".

No transcorrer da evolução no âmbito usos e costumes religiosos, objetos das mais variadas formas passaram a ser utilizados se tornando, a partir do primeiro uso, integrantes de cerimônias sacras e considerados de alto valor, a exemplo dos cálices até a decoração de sinagogas e templos. São recipientes confeccionados de prata ou ouro, cuja ornamentação visa a inspirar os fiéis na devoção pessoal. São também incluídos edifícios 
religiosos como a Basílica de São Pedro ou os magníficos templos hindus adornados de belos retalhos. Todavia, em certas Religiões como Islamismo e Protestantismo cristão existe reação contra ornamentação excessiva, uma vez considerar que esses efeitos distrai o alvo: a devoção.

Existem Religiões catalogadas e/ou classificadas em consonância à Região do globo terrestre das quais se originaram. Assim, Religiões como o Hinduísmo, Budismo e Jainismo compartilham a ideia de que a existência da vida constitui ciclo contínuo de nascimento, morte e renascimento (reencarnação) do qual o indivíduo religioso procura se libertar, sendo a Filosofia Espírita cristã estar atualmente no topo deste entendimento, lembrando que muitos consideram o Espiritismo classificado como Religião e outros, Filosofia.

Por outro lado, Religiões chinesas e japonesas têm crença em comum ao reverenciar Espíritos de ancestrais que partiram deste Mundo Físico: a Terra, a primeira maravilha do sistema solar contemplada com equivalência variada de água e terra, proporcionando a formação da Vida. Cumpre salientar, ainda, que a crença e a prática religiosas acontecem em inúmeros níveis; exemplo, um indivíduo reza, medita ou desempenha atos regulares de culto autonomamente, de modo a propiciar experiência individual em relação ao sagrado. Todavia para outras pessoas, a prática religiosa se trata de atividade social que deve ser compartilhada junto à família ou membros de uma tribo ou, ainda, à congregação local. Em pleno século XXI, cita-se exemplarmente os aborígenes da Austrália que realizam seus rituais em cultos nas proximidades das Montanhas Azuis, uma cordilheira misteriosa que homens de sabedoria, puros aborígenes, as classificam de "portal estelar"; em seu interior, paredes conservadas apresentam desenhos rupestres de civilização existida cerca de 40 mil anos atrás. Esses homens de sabedoria têm técnicas hipnóticas, por meio de sons reproduzidos alheios ao Mundo moderno e se dizem conectar com deuses celestiais. As reuniões visam a permitir aos participantes apoiar o próximo, a estudar Religião e a comemorar ocasiões em conjunto.

Cumpre salientar que, desde a Mãe África ao Continente australiano, grupos de povos indígenas praticam sua própria Religião, classificada como Religião Primeva. E como tais grupos se encontram totalmente espalhados pelo Mundo, suas crenças, por sua vez, variam de várias maneiras e aspectos; porém, a maioria delas tem elemento comum, isto é, a crença de que o planeta está repleto de Espíritos que exercem influências vitais ao conjunto da população mundial.

Por sua vez, a maioria das Religiões Primevas tem o seu Espírito Criador que em geral se trata de um deus celeste, além de série de Espíritos da Natureza como, também, divindades locais. O raciocínio filosófico: quando as pessoas morrem, entendese que elas sobrevivem no Plano Maior intitulado mundos espirituais e esse entendimento é agregado às Religiões Primitivas que acreditam que os Espíritos afetam suas vidas de 
vários propósitos; como exemplo, causando doenças, desastres naturais (tempestades, incêndios na floresta) ou beneficamente, curando doentes. Também, por sua vez, seres humanos entram em contato com o Mundo dos Espíritos, por meio de sonhos e visões, além de rituais normalmente praticados por um xamã ou curandeiro.

Até hoje, não se contabiliza com precisão - por ser muito difícil exatamente quantas pessoas seguem Religiões Primevas, porque são práticas de grupos isolados e estilo de vida tradicional; todavia, países como os EUA, México, Austrália, Nova Zelândia e quase todos os Estados africanos são modelos dessa prática, além do Brasil que se computa em ramificações do Espiritismo: candomblé, umbanda, quimbanda.

Premissa final: as Religiões Primevas têm desempenho fundamental na vida de indivíduos em todo o planeta, conforme visto, aborígenes australianos, índios hopi das Américas, tribos africanas e população das ilhas do Pacífico.

\section{O mundo invisível}

Reprisando, as Religiões Primevas praticadas pelas primeiras civilizações mostram a apreciação do homem pela Natureza como, também, a existência de provável Criador de todas as coisas. Lembra-se que todas as Leis da Natureza, na jornada da evolução da Vida, se chega a Deus. A primeira influência neste primeiro ensinamento veio com o profeta Zoroastro, fundador do Zoroastrismo por volta de 630 a.C. e se atribuem a ele os Gathas, hinos que fazem parte do Avesta, o Livro sagrado do Zoroastrista.

As Leis da Natureza são Leis Divinas, uma vez Deus o Autor de todas as coisas; o sábio estuda as Leis da Matéria, o homem de Bem, as da Alma e as segue. E é dado ao homem aprofundá-las umas às outras; todavia, uma só existência não lhe é suficiente para isso. O que são, de fato, alguns anos para se adquirir a constituição do Ser perfeito, embora não se considera mais do que a distância que separa o selvagem do homem civilizado? A mais longa existência possível é insuficiente e com mais forte razão quando é abreviada, o que acontece com grande número de pessoas.

Entre as Leis Divinas, umas regulam o movimento e as relações da matéria bruta: são as Leis Físicas e seu estudo pertence ao domínio da Ciência. As outras concernem essencialmente ao homem e às suas relações com o Pai Todo-Poderoso e com os seus semelhantes. Compreendem as regras da vida do corpo e as da vida da Alma: são as Leis Morais. Por último, Deus proporciona a todos os homens os meios de conhecerem a sua Lei; todavia, nem todos a compreendem: os que melhor a compreendem são os homens de Bem e os que desejam conquistá-la. Não obstante todos, sem exceção, a compreenderão, porque é necessário que o progresso se realize.

No âmbito das Religiões Primevas é cristalino o equacionamento das dificuldades e obstáculos encontrados em nossas vidas oriundo de causas provocadas por 
Espíritos do Mal; uns zombeteiros, outros daninhos junto a seus seguidores no intuito de reduzir suas influências, por meio de rituais que os agradem ou, melhor ainda, os afastem de seus propósitos. Nesses rituais, a maioria é conduzida por homens e mulheres aptos na comunicação com o Mundo espiritual.

No Brasil, rituais são enquadrados no candomblé, na umbanda e quimbanda, originários do Continente africano trazidos pelos escravos negros dominados pelos portugueses no período colonial. Das ilhas do Pacífico à tundra gelada da América do Norte encontram-se - nos dias modernos - pequenos grupos de povos indígenas que têm estilo de vida totalmente tradicional e muitos deles movimentam rigorosamente Religiões Primevas, assim intituladas porque existiam há milhares de anos, antes das modernas: Judaísmo, Cristianismo, Islamismo, Budismo ou Hinduísmo. E muitas dessas Religiões Primevas foram substituídas ou eliminadas pelas modernas, a exemplo do Cristianismo nas Américas e do Islamismo no Continente africano.

Obviamente, crenças e ideias divergem de um para outro povo ou, ainda, de área geográfica para outra; porém, muitas Religiões Primevas têm em comum determinados aspectos básicos e, acima de tudo, acreditam na existência de inúmeras legiões de Espíritos em total atividade que, por sua vez, exercem influência na vida da Humanidade: o Mundo Invisível. O conceito de que todas as coisas, animais, plantas, florestas, objetos inanimados são dotados da performance de determinado Espírito é conhecido como animismo e é parte fundamental das Religiões Primevas. Por sua vez, Espíritos podem habitar lugares da Natureza: montanhas, rios, lagos, florestas impenetráveis, vulcões ou, ainda, viver em planos de longa distância: céus e subterrâneos. E todos eles têm o próprio Poder especial sobre o Mundo Físico, incluso influenciar o pretenso alvo até às ações pessoais de determinado indivíduo. Premissa final: respeitar os Espíritos e agradá-los é parte vital e essencial da Religião Animista; é Lei Primeva!

Enfim, a conclusão nesta pesquisa é a de que indivíduos, animais, lugares e coisas têm proteção espiritual e poderosa; em parâmetro aos seres humanos podem agir de diferentes aspectos, isto é, para o Bem ou para o Mal e grande parte da doutrina da Religião Primeva se preocupa com o relacionamento humano - cada vez mais desgovernado da conduta social - com a do Mundo dos Espíritos, Mundo Invisível, pois se acredita que qualquer empecilho advindo pode afetar o cotidiano da vida dos indivíduos.

Lembra-se que cidadãos reverenciam Espíritos de ancestrais mortos, a exemplo do Hinduísmo e do Confucionismo ou do antigo Egito, na esperança de que eles transmitam suas preces a eles considerados protetores da Humanidade. Os hindus não-só acreditam em seus deuses como, também, os consideram vivos e integrantes atuantes em suas vidas sociais cotidianas.

A antiga civilização egípcia tem registro de antropólogos e historiadores - duração entre 3000 a.C. até meados do século I a.C. -, de período desenvolvido em 
Religião complexa, representada por meio de deuses diferentes, os quais evoluíram com versões deificadas de aspectos locais. Por devida consequência, certos deuses foram associados a lugares específicos; por exemplo, em Mênfis, Prá era como o Criador, mas em Heliópolis Rá-Aton era o supremo deus.

Com o passar dos tempos, os regentes do Mundo subterrâneo, Ísis e Osíris e o "deus Sol” assumiram muitas formas e influenciaram todos os aspectos da vida egípcia. Ressalta-se que o deus supremo Osíris e sua mulher Ísis governavam Duat (a explicação sobre Duat, logo a seguir) e se acreditava que ele tinha sido o primeiro Faraó, ensinando homens às artes da Agricultura e da civilização manual (engenharia, pintura, escultura e artesanato). Por sua vez, Hórus, seu filho, deus do Céu com cabeça de falcão, cujos olhos eram a Lua e o Sol, guiava as almas até Duat. Os egípcios acreditavam que as almas dos mortos iam para uma região subterrânea chamada Duat e para se entrar ali, o morto teria de passar por muitas provas, a fim de demonstrar que durante a sua jornada terrena tinha praticado o Bem.

Nesse complicado enredo se apreende que, quando cidadãos egípcios vinham a falecer, os seus corpos eram cuidadosamente mumificados - no intuito de preservação -, de maneira que os restos mortais possam ser utilizados no outro mundo. Raciocínio incompreensível em termos àqueles tempos: todavia, na modernidade antropológica científica, colaboração eficaz na identificação pelo DNA da sua autenticidade: se o vaso carnal (o corpo) pertencia a determinado Faraó ou descendentes de sua dinastia, como o acontecido na tumba encontrada do Faraó Tutancamon, o jovem Rei Tutti. Os egípcios ricos eram enterrados junto a todas as posses de valor pessoais que deveriam ser aproveitados em Duat. O caminho para Duat era de alta periculosidade e motivo de aprendizagem de encantamentos em texto intitulado O Livro dos Mortos, pretexto de proteção durante a jornada. E quando atingiam o coração - sede da consciência - era pesado na busca da determinação e se tinham, de fato, sido bons cidadãos!

Os animais eram venerados, tornando-se deuses no Egito antigo e de significativa variedade, desde a bondosa, elegante e meiga "deusa vaca" Hator, protetora das parturientes até às divindades aterrorizantes como a "deusa crocodilo" Sobek, fonte do poder do Faraó. A “deusa escorpião" Serket afastava o Mal e mesmo o "deus Sol” podia tomar forma de animal seja como o escaravelho Khepri ou o falcão Rá-Harakhry; o mais popular deus animal chamado Bastet era a deusa do parto e da sexualidade, sempre retratada como felino: o negro gato.

Os Faraós ou Reis do antigo Império egípcio (2700-2200 a.C.) e do médio Império (2000-1800 a.C.) eram sepultados em pirâmides de pedra maciça destinadas no auxílio ao alcance da vida eterna; no centro de cada pirâmide - o que se aprende por meio de guias turísticos em visita ao Egito - ficava a câmara mortuária na qual se abrigava a tumba do Faraó ornamentada de bela e rica decoração de puro ouro junto às suas posses 
pessoais. O conjunto incluía um templo mortuário onde os ritos fúnebres eram realizados anualmente e a forma da pirâmide recordava o montículo, local do "deus Sol” no momento da Criação do planeta.

O Faraó egípcio era considerado o filho do "deus Sol" ou, ainda, a encarnação desse deus, cuja crença se originou durante a $5^{\text {a }}$ dinastia (2465-2323 a.C.), quando se difundiu que três faraós eram filhos de Rá e da esposa de um de seus sacerdotes: a partir daí, o Faraó passou a ser intitulado "filho de Rá". Os egípcios acreditavam que Hórus, “deus do Céu” e o deus íbis Thor, “deus da Lua”, que anotava os nomes das almas no mundo subterrâneo, intervinham durante a coroação dos Faraós, dando-lhes a condição divina. Essa condição era renovada todos os anos na cerimônia do Jubileu do Rei.

Após o século IV a.C., o Egito passou a ter governantes gregos e romanos. Esses líderes cultuavam deuses da Grécia e da Roma antiga; todavia, tratados como Faraós, uma vez o povo egípcio manter as velhas crenças; e seus corpos continuaram a ser mumificados, na morte. Dentre os líderes, a bela Rainha Cleópatra, de inteligência incomum, tratou de assimilar idioma, ritos e usos e costumes egípcios, embora educada aos moldes do estilo grego. Neste elenco, Alexandre III, conhecido como Alexandre, o Grande, da Macedônia, filho do Rei Filipe e da Rainha Olímpia, suspeita de promover a morte do marido, assassinado em 336 a.C., fato que fez com que Alexandre ascendesse ao trono. Ele é considerado um dos homens mais belos na passagem deste Mundo e surpreendente pela astúcia militar, política e habilidade fantástica, além de dominar o Egito, as cidades Estado-gregas e de se ter lançado à conquista do vasto Império persa. Em universo pagão, Alexandre, no Ocidente, tinha sua própria Religião Primeva junto à virtude pessoal inigualável: a Fé, além de possuir exímia mediunidade; nos mesmos moldes vivenciaram Gengis Khan, na Mongólia, e mais tarde o imperador Constantino, oficializando o Cristianismo ao Império romano. Todavia, o Paganismo ainda reinava em grande parte da Humanidade.

\section{Sumérios, Babilônios e Assírios. A Pérsia (atual Irã)}

Arqueólogos pesquisadores e historiadores relatam evidência - ao longo do período 2600 a.C. a 330 a.C. -, que sumérios, babilônios e assírios da Mesopotâmia tinham o hábito de cultuar série de deuses; a maioria, segundo pesquisas das primeiras escritas em pergaminhos e segundo a crença originária, de um mar primevo, antes da formação da Terra e seus primeiros habitantes há mais de 600 mil anos. Provavelmente, se trata de divindades superiores como o "deus Sol Utu" que governava parte do Cosmo. Outras divindades, Ninmah, deusa do nascimento, controlava áreas essenciais da Vida humana. 
Estas estupendas e grandes primeiras civilizações surgiram no Oeste da Ásia; ruínas de templos, esculturas e placas de argila desenham hieróglifos que subsistiram e, por sua vez, informam sobre suas regulamentações religiosas. As divindades importantes eram as que surgiram no Cosmo, a exemplo do Sol e da Lua, esta até então inexistente no início da formação deste planeta Terra, repleto de propriedades de elementos especiais, tais como abundância de águas trazidas pelos asteroides ... valioso presente à origem da Vida. Os ancestrais acreditavam que os deuses controlavam o clima, ou seja, as estações e as condições anômalas. $\mathrm{O}$ amadurecimento das culturas e o suprimento de alimentos eram repassados pelos deuses; daí a evidência das oferendas em templos gradativamente serem integradas à rotina de subsistência da Vida, cujos mediadores eram os sacerdotes. ${ }^{3}$

A Região mesopotâmica era constituída em parte da cidade de Ur que se tornara a mais importante, localizada às margens do Rio Eufrates e capital do Império mesopotâmico, por volta de 2100 a.C. No centro desta cidade muitos templos, incluso o grandioso Zigurate, consagrado à divindade protetora da civilização, a "nova Nana", deusa da Lua, surgindo esplendorosamente, cujo símbolo era a Lua Crescente. Outras famosas, a "deusa Tiamat", era o oceano de água salgada e representava o caos da criação e as divindades mesopotâmicas surgiram quando Tiamat se uniu ao seu consorte Apsu, deus da água doce, suprimento essencial à Vida. Viviam esses deuses em plena harmonia; todavia, posteriormente, entraram em guerra, quando Tiamat foi morta por seu filho, Marduk; metade do seu corpo virou o Céu e a outra, a Terra. Por fim, Ishtar - chamada também de Inana - venerada em toda a Ásia ocidental: torna-se a mais importante deusa do Paganismo e importante figura da Religião Primeva.

Ishtar, na Assíria, era a deusa da guerra, mas na Mesopotâmia deusa do Amor e da Fertilidade, visitava o mundo subterrâneo anualmente; na estação inverno, acarretando o enfraquecimento e escassez dos vegetais, significava a reflexão de sua ausência. Na Ásia ocidental, composta de três áreas: Mediterrâneo Ocidental, Mesopotâmia (entre os Rios Tigre e Eufrates incluindo a Assíria, Suméria e Babilônia) e a Pérsia foram o berço de notáveis tradições religiosas divergentes.

\footnotetext{
Quando foram realizadas escavações na antiga cidade Cananeia de Ugarit, na década de 1920, foram encontradas placas de argila que mostravam lutas entre os deuses, o que parecia explicar a mudança das estações. El, o deus criador cananeu, era conhecido como o pai dos deuses e dos primeiros humanos; vivia na nascente de todos os rios. Asherat era mulher de El e mãe de setenta divindades, conhecida como Astarté na antiga Grécia e tornou-se Afrodite; na Mesopotâmia, Ishtar. Entre os cananeus, o deus Baal, cujo nome significa "senhor" - que foi dado ao deus local em muitas outras cidades da Ásia Ocidental; a sua forma mais conhecida é Baal-Hadad, o deus cananeu do trovão e da fertilidade. Na Mitologia, Baal lutou contra o monstro aquático Yam e reafirmou seu controle sobre as chuvas que favoreciam a vida. O inimigo de Baal era Mot, deus da morte, associado com a esterilidade e a seca. De acordo com a lenda, os dois deuses lutaram ferozmente e o deus do trovão parecia ter sido derrotado; milagrosamente, Baal ressuscitou quando as chuvas retornaram após a estação seca.
} 
No século XVII a.C., torna-se notória a cidade da Babilônia reconstruída pelo Rei Nabucodonosor II, capital do Império babilônio, totalmente renascida. Nela, prédios sagrados em toda parte com templos construídos aos principais deuses, incluso Marduk, o deus criador e a deusa Ishtar. Cada um dos portões fora dedicado a uma determinada divindade e os muros apresentavam símbolos religiosos tais como dragões que, por sua vez, representavam o próprio Marduk, além de touros ao deus do tempo e do trovão, Hadad; os leões eram símbolos de Ishtar.

Nabucodonosor II em certo período de sua vida fora influenciado pelos judeus levados para a sua cidade após a invasão de Jerusalém, torna-se crédulo do Deus Único e defensor exímio na obediência ao Código de Hamurabi, criado por seu pai, editado com normas jurídicas severas, dando poder ao Rei exigência aos cumprimentos da Lei, incluso usos e costumes e conduta social. A transgressão, condenava o infrator à morte, após veredito real. Dentre as punições, o enforcamento em praça pública. Muitos judeus sofreram punição em seu Reinado. Enfatiza-se como um dos primeiros diplomas jurídicos da História do Direito: o Código de Hamurabi.

Por outro lado, os templos mais importantes da Mesopotâmia eram construídos sob a forma de zigurates: altas torres com andares, algumas de até $45 \mathrm{~m}$ de altura, realizadas por meio de adobe; no topo, pequeno santuário considerado pelo povo a residência divina dos deuses. Os degraus eram distribuídos ao longo das torres e para os mesopotâmios, a finalidade da subida pelos degraus servia para se chegar aos Céus; só que ninguém tinha permissão para subi-los!

Com relação à Pérsia, a Religião era versada pelo Zoroastrismo - Religião Primeva de mais de 2.500 anos que se estende entre os séculos VIII e V a.C. - recebendo esse nome em homenagem ao seu fundador, Zaratustra. Segundo esse profeta, a vida é uma luta constante entre os deuses do Bem e do Mal e ainda existem comunidades zoroastristas modernas que, para encontrá-las, historiadores e pesquisadores percorreram as regiões do Irã e da Índia, cujos integrantes são os parses. Zoroastro fundou o Zoroastrismo por volta de 1000 a.C. e se atribuem a ele os Gathas, visto acima, hinos que fazem parte do Avesta, Livro Sagrado da Zoroastrista, conforme já verificado. Nele, um mito persa: Zurvan, o deus do tempo, homem e mulher ao mesmo tempo, que existia antes de todas as outras coisas e que dera origem a Ahura Mazda e a seu irmão gêmeo, Espírito do Mal, Angra Mainyu. Ahura Mazda, "deus do Céu" ou "Sábio Senhor" era considerado a fonte de todo o Bem terreno. Os sacerdotes persas ensinavam que ele venceria a guerra contra Angra Mainyu e o Universo; assim, ficaria livre de todo o Mal, o que nunca aconteceu!

Cumpre salientar, por último, que Angra Mainyu, deus das trevas, da morte e do Mal propositadamente criava assustadoras tempestades com raios e relâmpagos aterrorizantes como, também, pragas e monstros perigosos durante a sua luta contra Ahura Mazda, o irmão gêmeo! Os zoroastristas ensinavam que Angra Mainyu se tornara 
necessário ao discernimento das ações individuais, porque só se pode compreender o Bem quando o Mal também está presente, conteúdo inclusive assimilado posteriormente pelos gregos em fantásticas lições de Filosofia.

Os antigos persas tinham o hábito de preparar uma bebida inebriante, por meio da seiva da árvore haoma - conhecida como árvore da vida - , à qual se acreditava de o vegetal ter vindo do Paraíso, sua origem; diziam que trazia saúde e fertilidade, incluso a imortalidade. Mais tarde, sacerdotes zoroastristas adotaram hábito cotidiano de beber haoma, tornando-se parte dos ritos desta Religião Primeva.

Finalizando, os fenícios: civilização de exímios navegadores da Costa Leste do Mediterrâneo que compartilhavam com os cananeus o culto dos deuses El Baal e Asherat; contudo, importavam divindades de outros povos, a maioria dos quais ao comércio, enfatizando deuses do antigo Egito. Algumas das estátuas de seus templos eram semelhantes às dos deuses egípcios Ísis e Hator, a meiga deusa Vaca. Computa-se neste longínquo período o épico poema Gilgamesh, ${ }^{4}$ obra literária mais antiga de toda a História da Humanidade (2000 a.C.).

Nela, a narrativa de como o povo de Urak, na Mesopotâmia, pediu aos deuses providências contra o tirânico Gilgamesh, posteriormente o Rei de Urak e mais tarde deificado. Gilgamesh adorava aventuras junto ao amigo Enkidu e quando seu amigo morreu, ele chorou por vários meses, levando-o à procura da imortalidade, aproximandose de seu ancestral Utnapistin, único homem a quem tinha sido concedido a imortalidade, o qual, por sua vez, disse a Gilgamesh que ele fosse ao mundo subterrâneo para recuperar uma planta mágica. Ele a encontrou de fato; todavia, uma gigantesca serpente a engoliu antes que ele pudesse voltar à Terra: nesta narrativa, a imortalidade, nesta encarnação, não

$4 \quad$ O antigo herói da Mesopotâmia, Gilgamesh, é o primeiro símbolo da busca da imortalidade, em toda a Literatura mundial, embora haja uma pergunta que permanece no ar: esse extraordinário homem teria existido? Desde tempos imemoriais, o homem tem sonhado com heróis capazes de desvendar os mistérios do mundo espiritual e o segredo da vida eterna. Gilgamesh é considerado o primeiro deles ou, pelo menos, o primeiro que buscou respostas a essas perguntas. O "Épico de Gilgamesh" é muito mais antigo que a "Ilíada", de Homero ou o grande épico indiano, "Mahabharata" e é, sem dúvida, o mais antigo texto épico do Mundo, porque se sabe que a sua primeira versão foi escrita pelos sumérios na metade do segundo milênio a.C. Os numerosos fragmentos do "Épico de Gilgamesh", do qual existem muitas versões, foram encontrados em diferentes partes do Oriente Médio e o fragmento mais completo foi localizado em Nínive, na sede da famosa biblioteca do Rei assírio Assurbanípal. Datada, esta versão da lenda, do século VII d.C., gravada em doze tábuas de argila; três delas nunca foram encontradas. A décima primeira tábua, inclusive, narra a história de grande dilúvio, a versão babilônica do dilúvio relatada na Bíblia. Gilgamesh teria vivido por volta de 2700 a.C., na cidade de Uruk, Sul da Mesopotâmia, onde era Rei e notável governante, uma vez construtor de enormes muralhas, em torno da cidade, e templos imponentes, cujos vestígios ainda podem ser vistos na atualidade. Enfim, o "Épico de Gilgamesh" desperta interesse quase universal, talvez por dar forma a questões que intrigam a Humanidade, através dos séculos: as relações com os deuses, o poder da amizade, o orgulho e a fúria, a vulnerabilidade, o amor, a morte e, por último, o sentido da vida. Ele é alguém que tenta responder a essas eternas perguntas e, por isto, tem chance de se tornar imortal. 
nos é possível! Os deuses também falham e Utnapistin também desapareceu; nada se sabe sobre o seu paradeiro.

\section{Os mitos escandinavos e celtas}

A necessidade inafastável das antigas sociedades ancestrais, desde o Período Neolítico, era o de regrar a vida dos agrupamentos humanos que estavam a se formar. Assim, normas de conduta, éticas ou legais, eram devidamente decretadas pelos deuses e, por sua vez, executadas por sacerdotes, lembrando que outrora a Lei humana dimanava diretamente dos deuses e das Religiões Primevas e Reveladas que tinham julgamentos dos homens aos moldes dos sistemas jurídicos legislados pelos próprios homens, uma vez as Leis do homem com cumprimento a ser seguido, sob pena de aplicação de sanções, diferentemente da posterior Lei de Deus, advinda na época de Moisés, a Lei mosaica.

Relíquias da Religião Primeva encontram-se nas antigas sociedades do Norte e Oeste europeu, computando-se escandinavos, finlandeses, celtas e eslavos que, além de darem importância às guerras, por meio dos deuses guerreiros, acreditavam como os egípcios na vida post-mortem. Nessas regiões, o efeito da mudança das estações sobre a Agricultura era vital à sobrevivência. Assim, se realizavam festivais sazonais regulares para conseguir a fertilidade do solo e bom suprimento de alimentos, consonância à Lei da Sobrevivência.

O culto era realizado por meio de oferendas e sacrifícios. Acreditava-se que os líderes religiosos podiam prever o futuro. Além da rica variedade de crenças religiosas, as Regiões escandinavas compartilhavam um grupo de divindades e crenças semelhantes, enquanto as terras celtas (Irlanda, Grã-Bretanha e Norte da França) tinham crenças inteiramente diferentes.

Dentre os mitos, a de que os mortos seguiam para o negro domínio de $\mathrm{Hel}$, outro mundo escandinavo assim chamado, situado embaixo da terra, nas raízes de Igdrasil, gigantesco freixo também chamado de "árvore da vida", o qual unia todo o Cosmo escandinavo. Nos ramos mais altos se situava Asgard, o lar dos deuses; mais abaixo, Midgard, a parte da terra habitada pelos humanoides terráqueos, parte ligada a Asgard pela Ponte Bifrost. Sob a terra, entre as raízes da árvore, havia série de domínios onde os mortos, os gigantes e as Nornas controlavam o destino dos humanos.

Mas os heróis de guerra aguardavam destino melhor: vida junto a Odim, deus da guerra, no Paraíso dos Guerreiros intitulado Valhala, local de treinamento para a Batalha de Ragnarok. Segundo as lendas escandinavas um grupo de deuses criadores Odim, Vili e Ve - lutou contra o cruel gigante Yrnir, matando-o e utilizando o seu corpo para criar o Mundo; seus dentes na criação de rochas; a carne, a terra e o seu sangue, rios e mares. Acima da terra, os deuses colocaram o gigantesco crânio de Yrnir que se 
transformou no Céu e o cérebro serviu de formação às nuvens. Assim, os deuses criaram o primeiro homem chamado Ask e a primeira mulher, Embla, feitos de duas toras de madeira encontradas na praia do litoral escandinavo, os quais se tornaram os pais da raça humana.

Os homens ancestrais da civilização escandinava acreditavam que o Universo iniciou como gelo e fogo e esse primeiro gigante visto acima, Yrnir, fora criado onde os dois sistemas se juntavam. O suor de Yrnir dera origem a dois outros gigantes que também se tornaram pais de uma raça de gigantes que habitavam montanhas como, também, no mar e nas nuvens. Eles tinham o hábito de travar batalhas contra deuses; todavia, por fim, o supremo deus Odim ofereceu aos gigantes um território chamado Jotunhein, localizado nas raízes de Igdrasil.

Os enredos das lendas escandinavas são fascinantes; todavia, requer minuciosa e infinita interpretação, mas finita é a dedução de que esses ancestrais escandinavos mantinham contato com seres estelares de alto nível, os quais passaram conhecimentos não-decifráveis. ${ }^{5}$

Segundo os escandinavos, Asgard era uma cidade amuralhada e cercada por belos campos verdes, dos quais proviam alimentos cultivados pelos deuses que lá viviam; dentre eles, Thor, deus dos trovões e dos raios, muito poderoso e extremamente popular. Outro deus Njörd, dos mares, pai de Freia, deusa da abundância. O líder de todos era Odim, ${ }^{6}$ o deus da guerra.

A civilização celta também tinha numerosos deuses e muitos deles controlavam as estações do ano propiciando fertilidade, safras abundantes e fartura de alimentos, realizavam festas sazonais como Beltaine, Festival da Primavera, no mês de maio, Lugnasad, em agosto; Oimelc, em fevereiro e Samhain, a festa de Ano-Novo no mês de novembro. Embora os celtas não tenham deixado registros extensos, como os escandinavos, conhece-se a sua Religião Primeva, por meio de escritos romanos.

\footnotetext{
5 Por exemplo, o Universo, segundo ancestrais escandinavos, se iniciou com gelo e fogo; porém, na jornada da criação da civilização, o que queriam reproduzir provavelmente era uma nave espacial prateada (gelo) que, em movimentos, expandia luzes de maquinário incompreensível aos conhecimentos humanos (fogo). Pela lógica, a conclusão dedutiva de visitas de seres avançados que atualmente denominamos extraterrestres, no intuito de trabalhos à composição da criação de novo planeta. Não-só para os ancestrais escandinavos, celtas, egípcios e outros essa era a visão do Mundo que até então eles obtinham, assim como para os índios hoppie, EUA, ou dos primeiros aborígenes nômades australianos das Montanhas Azuis. São enredos similares encontradiços em milhares de cavernas rupestres, primeiro abrigo aconchegante de nossos ancestrais!

6 O segundo ser a ser criado foi a vaca Audumla que se originou como Ymir do gelo derretido. Do seu úbere corriam rios de leite que fornecia de alimento aos gigantes e a única comida que Audumla podia encontrar para si era o sal do gelo que ela lambia avidamente. E enquanto a vaca lambia o gelo, apareceu a cabeça de um homem, o belo e forte Buri, sendo assim libertado do gelo. O filho de Buri, chamado Bor, se casou com Besla, filha de um dos gigantes do gelo e os filhos de Bor e Besla foram os deuses Odim, Vili e Ve.
} 
Dentre os deuses celtas, aponta-se Sucellus, o deus da Primavera conhecido como "Rei dos Deuses", qualificado como "muito importante", porque os celtas dependiam de plantas e árvores ao suprimento dos alimentos e não se olvida ser a Região celta, em grande parte do ano, sempre revestida de gelo. Sucellus carregava enorme martelo, por meio dele batia na terra congelada para acordar a vegetação e fazê-la reviver; também pode ter sido símbolo de sua autoridade divina em parâmetro ao cetro dos Reis. Na cultura celta, se destacam também Épona, deusa dos cavalos associada concomitantemente à fertilidade e às águas doces potáveis. Taranis, deus dos trovões, que se assemelhava ao deus romano Júpiter. Os celtas acreditavam que o trovão era causado em poderoso ruído produzido pela roda da carruagem de Taranis e o relâmpago vinha das centelhas despendidas pelos cascos dos equinos! Todos esses detalhes são encontrados em afrescos registrados e expostos no Museu Britânico, de Londres.

Na História celta, um dos deuses mais antigos se chamava Cernunnos, o Cornífero, representado com os chifres de um veado macho e tido como o "Senhor das Feras"; geralmente figurado junto aos demais animais da Região, especialmente serpentes, e muitas vezes alimentando-os, sugerindo que Cernunnos era um deus da abundância que, por sua vez, domesticava todas as criaturas selvagens, oferecendo-lhes alimentos; tornando-se, consequentemente, um dos mais poderosos deuses celtas. O líder celta Brennus, que invadiu Roma, era adorador do deus Cernunnos.

Por último, Lugh, apelidado de "o Brilhante"; era o deus do Sol celta, habilidoso em todas as Artes e Ofícios. Ele construiu um barco mágico chamado "Varredor de Ondas", totalmente dourado e na forma de um ovo, lembrando, assim, o Ovo Cósmico que, desde a aurora da civilização, o ovo se faz representado em todas as Nações deste Mundo, símbolo da fertilidade. Lembra o óvulo, origem do nascimento e em culturas radicalmente diferentes das mais antigas, Babilônia, às modernas, Portugal (“o Ovo" do Museu de Algarve), Grécia, Espanha, Grã-Bretanha ou a Ilha de Páscoa, esta por ter sido descoberta em período da comemoração da Páscoa.

Os líderes religiosos celtas, druidas, eram rigorosamente treinados na aprendizagem de todos os campos de Artes, ao longo das suas vidas; controlavam a vida religiosa dos demais cidadãos de suas aldeias, presidiam sacrifícios e oferendas, ofereciam conselhos sobre dúvidas nas questões da Religião Primeva, enfatizando as espirituais e prediziam quando era a melhor época para semear plantações ou, ainda, pôr em tempo correto o rebanho a pastar. Os druidas tinham conhecimento de ervas e suas respectivas curas, além da atuação como juízes de disputas em geral. Eles orientaram a Rainha Boldica, da Região da Bretanha, na preservação de suas terras contra os romanos, cuja liderança do Exército fora de Sueltônio Paulino. Ela se suicidou, após a derrota da tribo que liderava. 
Os mitos celtas foram difundidos por toda a Grã-Bretanha, Irlanda e França ao passo que as constantes viagens dos povos escandinavos - significativo grupo da Escandinávia pagã concentrado na cidade de Uppsala - e germânicos explicam a semelhança das várias lendas sobre conflitos entre deuses e monstros. Nos mitos eslavos e finlandeses há também divindades e Espíritos da Natureza. Apesar da variedade, há temas comuns a toda a Mitologia nórdica e cada cultura tem seu mito da criação com responsáveis diversos, desde Odim dos escandinavos visto acima até a "moça-de-ar" dos finlandeses, que trazia abundância de chuvas.

Por fim, muitas lendas se referem a heróis, guerreiros e Reis que garantiram seu atual território e a Natureza é presença constante. Os Espíritos das florestas e dos violentos mares setentrionais exercem papel fundamental. Os primeiros narradores dos mitos escandinavos foram transmitidos oralmente, mas no início da Idade Média alguns eruditos como o escritor, jornalista e historiador Snorri Sturlson, da Islândia, registraram inúmeras histórias da Região. Os mitos celtas também foram escritos nessa época. Entretanto a Mitologia eslava e a finlandesa continuaram sendo orais até serem reunidas ou recolhidas por estudiosos dos séculos XIX e XX; muitos desses documentos são encontrados, para pesquisa, em bibliotecas inglesas e francesas.

\section{Dos deuses governantes aos Reis Faraós}

A adoração aos deuses gradativamente esmorecia substituída pelo poderio dos Reis e Faraós míticos e poderosos na jornada da História da Humanidade; nas antigas civilizações o conceito ao Deus Único estava longe de ser assimilado, a exemplo da gloriosa civilização egípcia que permaneceu cerca de 3000 a.C. até o século I a.C. em longo período desenvolvendo uma Religião complexa, constituída de inúmeros deuses evoluídos em versões deificadas de aspectos locais. Em consequência, determinados deuses foram associados a específicos lugares, a exemplo de Mênfis, onde Prá era tido como o criador, mas em Heliópolis Rá-Aton era o supremo deus. Alguns anos, divindades adquiriram importância nacional, haja vista a qualificação dos regentes do mundo subterrâneo, Ísis e Osíris e o deus do Sol assumirem formas diversas e influenciando aspectos da vida no Império egípcio.

A vida egípcia era totalmente regulada pelo Rio Nilo, principal fonte vital da subsistência: água; e o deus da inundação do Nilo era Hâpi, chamado "o Senhor do Rio que Traz Vegetação" em referência à fértil lama do Nilo, abundância em atividade nos tempos modernos. Esse "senhor" era representado como figura humana, possuindo plantas aquáticas sobre a cabeça, além de ser ilustrado portador de seios e barriga volumosos, símbolos de fertilidade. 
Dentre os deuses do Egito, alguns tomaram a forma de animais; havia enorme e significativa variedade, a saber: a meiga deusa vaca Hator, protetora das parturientes às divindades aterrorizantes, o deus crocodilo Sobek, fonte do poder do Faraó. E mesmo o "deus Sol” podia adquirir a forma animal, seja como escaravelho, Khepri, ou falcão RáHarakhty, personagens assimilados pelos diretores de Arte e produtores cinematográficos dos EUA ("A Múmia"/“A Tumba do Faraó"). Por último, um dos mais populares desses animais, Bastet, a deusa do parto e da sexualidade, sempre retratada como um felino: o negro gato!

O Faraó, respeitado por ser consumido como o filho do "deus Sol” - incluso a encarnação desse deus -, tinha a crença originária no período da V Dinastia - 2465-2323 a.C. - difundido até a gestão em que três últimos Faraós eram considerados filhos de Rá e da esposa de um dos sacerdotes do Império. Desde então, o Faraó passou a ser intitulado o "Filho de Rá", conforme registrado acima.

A civilização egípcia acreditava e venerava Horus, deus do Céu e o deus íbis Thot, o deus da Lua que tinha a tarefa de anotar os nomes das almas que partiam ao mundo subterrâneo, ambos intervinham durante a coroação do Faraó, dando-lhe a condição divina; a partir daí a condição era renovada anualmente: a Cerimônia do Jubileu do Rei. Com relação aos sacerdotes - assim como os da Babilônia -, os do antigo Egito trabalhavam em diversas tarefas tanto administrativo-financeiras, juízes do Estado, autores de normas jurídicas internas, provedores do Censo anual quanto na documentação de bibliotecas. Os sacerdotes-chefes vinculados aos importantes membros da Corte eram administradores dirigentes dos imóveis palacianos, selecionando equipes e atuantes representantes do Faraó. Abaixo do sacerdote-chefe, ao mais velho, a incumbência de realizar oferendas aos deuses do templo. "Deus" era o próprio Faraó que assim acreditavam, pois tinha sido educado aos preceitos ancestrais junto à civilização humilde e composta de exímios trabalhadores, a maioria remunerada com alimentos e muito pouco escravo.

Após o século IV a.C., o Império egípcio teve governantes gregos e romanos e esses novos líderes cultuavam tanto deuses da Grécia quanto os de Roma, nesta ordem, porém retratados como Faraós, uma vez a civilização manter velhas crenças, incluso modus vivendi ou o hábito do embalsamento: acreditam na vida após a morte!

\section{Grego/Romanos}

É ciência dos estudiosos de que na Antiguidade as Leis eram interpretadas pelos Reis que tinham o poder da punição ou-não; a população aumentava e os respeitavam, ao mesmo tempo, a obediência aos sacerdotes era impecável; todavia, estátuas de pedra continuavam veneradas, uma vez difícil a compreensão de um Deus Único e invisível. Por meio da aprendizagem coletiva, seguida da revolução agrícola gradativamente em 
evolução, na qual a Religião Primeva fazia parte no dia a dia greco-romano. Época em que a maioria das casas e oficinas tinha santuários particulares; no seu interior, estátuas de ancestrais e deuses domésticos, a exemplo de Lares ou Penates, deuses do lar e das despensas, respectivamente. Ressalta-se, junto ao respeito, a tarefa do chefe de família: o de realizar rituais cotidianos simples, lembrando que tanto gregos quanto romanos construíram templos aos deuses clássicos em todas as cidades da época antiga, incluso nas dominadas por estas civilizações.

Os romanos tomaram emprestado todos os deuses dos antigos gregos, dando-lhes nomes diferentes como a da deusa do Amor, Afrodite, para Vênus ou Ares que virou Marte; todavia, nativos prevaleceram como o deus criador Jano, de duas faces, relacionado às entradas dos portões das cidades conquistadas e de Roma. O Rei dos deuses romanos - equivalente ao supremo deus grego Zeus -, é Júpiter, venerado como protetor do Estado romano, além de defensor da Justiça e um dos maiores templos em sua homenagem, Optimus Maximus, tem os seus alicerces erguidos até hoje; encontra-se à vista e preservado na Roma moderna.

Os romanos valorizavam o deus Marte, pela virtude da força, e inventaram seus próprios mitos sobre ele, incluso a história de que Marte era o pai de Rômulo e Remo, ${ }^{7}$ fundadores de Roma. Após a Cidade Eterna se tornar o maior Império de todos os tempos, passaram a se referir ao imperador como "o filho de deus", em parâmetro aos egípcios "filho do Sol" e muitos imperadores foram elevados à condição de deuses pelo Senado romano, mesmo depois de mortos. Por outro lado, Calígula (12-41 d.C.) e Domiciano (51-96 d.C.) foram considerados deuses ainda em vida.

No Norte da Itália, etruscos - que governavam a Região antes dos romanos -, portadores de incrível criatividade criando ali uma Religião Primeva etrusca. Eles foram influenciados pelos gregos, em cômputo de deuses semelhantes às divindades grecoromanas: um deles, Tin, o mesmo que Júpiter ou Zeus; Turan como Vênus ou Afrodite; Menvra como Minerva ou Atena.

\footnotetext{
Segundo infindáveis relatos da História romana, os gêmeos Rômulo e Remo, filhos de uma princesa da cidade de Alba Longa, foram abandonados às margens do Rio Tibre, logo após nascerem; uma loba os encontrou, adotou-os e os alimentou. No local, romanos decidiram construir uma cidade, cujo lugar, posteriormente, foi chamado de Roma. Da primeira retratação - pelos antigos escultores - da loba disponibilizando as tetas aos gêmeos, várias réplicas surgiram ostentando os principais espaços físicos públicos italianos. Até hoje cópias da escultura são consumidas em infinita aquisição pelos visitantes da Eterna Roma. Mister também conhecer a história de que o poeta Virgílio (70-19 a.C.) escreveu epopeia tão famosa quanto a escultura intitulada "Eneida" que narra a vida do herói Enéias, filho do Rei Anquias e da deusa Vênus, ancestral de Rômulo e Remo. O propósito do poeta Virgílio era o de demonstrar que os primeiros governantes de Roma tinham origem divina, relacionando, dessa forma, os posteriores imperadores com os deuses. A dissociação do binômio imperador/deuses somente veio a acontecer no Império de Constantino I.
} 
Os gregos acreditavam que antes de os seus deuses(as) terem nascido, existiu uma raça de seres gigantescos chamados Titãs e dois deles, Réia e Cronos, foram os pais dos demais deuses. Narravam a prevalência de que os seres humanos teriam sido criados por Prometeu que os formara por meio do barro ou, ainda, pelo deus supremo, Zeus. O conjunto de pergaminhos é cognominado "bíblia de barro", encontrado por arqueólogos daquela Região Norte etrusca.

Por intermédio dos filósofos gregos, o conceito de deuses e deusas foi aos poucos sendo eliminado do pensamento humano, mesmo porque até eles não podiam vencer as forças da Natureza e consequentemente da pauta da História da Religião, período que passa a ser instruído pelo Judaísmo, ensinado por um "Povo do Livro" escolhido pelo verdadeiro Deus Único, espalhando-se por todo o Mundo até 1948, nascimento do glorioso e magnífico Estado de Israel.

\section{Judaísmo}

Em preâmbulo, se trata do primeiro patriarca, Abraão e seus imediatos descendentes, narrada no Gênese e revelada em três períodos, abrangendo roteiro dos primeiros assentamentos hebreus em Canaã, atual Israel. Dos três períodos, o primeiro, associado a Abraão em Hebron, 1850 a.C.; o segundo, abrange o neto dele, Jacó que se estabeleceu em Chechen (hoje, Nablus, Cisjordânia). Nesse período, Jacó e seus doze descendentes - origem das doze tribos de Israel - emigraram para o Egito, evasão forçada motivada pela escassez de alimentos em Canaã. O terceiro, ocorrido em 1200 a.C., quando tribos que se diziam descendentes de Abraão chegaram a Canaã, vindos do Egito. O último período é o do assentamento, identificado pela escravidão sofrida pelos Faraós egípcios, os quais alegam terem sido libertados graças à divindade chamada Javé, Deus de seu chefe: Moisés.

Após mais de 400 anos de escravidão, a legião liberada - vinda das terras egípcias - entra após obstáculos e lutas em Canaã, aliando-se definitivamente aos hebreus nativos. Dessa união conhecida como "Povo de Israel" ressalta-se que a Bíblia hebraica mostra evidências de que o Povo que se conhece como "antigos israelitas", na verdade se trata de antiga confederação de vários grupos étnicos ligados por sua lealdade a Javé, o Deus de Moisés.

Enquanto os hebreus retornavam a Canaã, fato histórico acontecia: Troia havia sido destruída pelos gregos e nesse contexto uma guerra deflagrada, mais tarde narrada em versos pelo grego Homero composta por heróis como Heitor e Aquiles, Enéias e Ulisses, Páris e Agamenon; parte do elenco da história desse confronto, obrigou a emigração dos vencidos e aliados de Troia; dentre eles, filisteus chamados de "homens do mar" a se estabelecerem em Canaã. Inclusive esse povo chegou a lutar contra o poderoso 
Império egípcio, na defesa de seu território, Canaã; na época de Moisés, era dividida em cidades e cada qual com perfil próprio de governo. Para um Povo que havia passado 40 anos divagando pelo deserto não poderia ser tão fácil conquistá-la, uma vez cidade amuralhada, repleta de guerreiros e torres com sentinelas fortemente armadas. A favor dos hebreus, a Fé em seu Deus Revelado, orientando-os em mais de trinta batalhas, virtude comandada por Josué, substituto e sobrinho de Moisés, após a sua morte. A primeira cidade vencida, Jericó, na época uma das mais prósperas terras em território canaense.

A luta pela conquista da Terra Prometida, editada pelo próprio Deus, se estendeu por cerca de 200 anos, período que tanto cananeus quanto hebreus não estavam unidos; pelo contrário, divergentes e divididos em usos e costumes e na conduta social. Em dois séculos não tinham conquistado o propósito, época da escolha de um Rei pelo Povo, chamado Sem, na função primordial de comandante supremo. O denominador comum - entre os hebreus - era o da identificação pela circuncisão, obrigatória.

Esses fatos foram narrados, oralmente, de geração em geração assim como ensinamentos religiosos junto à Fé em um Deus Único; na jornada, David, posteriormente aclamado Rei conquistador de parte daquele território cobiçado; outro descendente, Salomão, torna a Região em poderosa e rica cidade e a construção do primeiro templo de Jerusalém. Todavia, após a sua morte, o Reino é dividido em dois poderes: o do Norte passa a se chamar Israel e o do Sul, Judá, em guerra um contra o outro. Do confronto, a interferência babilônica que conquista Israel e Judá, época do Rei Nabucodonosor II, que escraviza hebreus e se encanta, posteriormente, pelos ensinamentos dos sacerdotes judeus da Região vencida, a ponto de se tornar convertido à devoção de um Deus Único, pouco antes de sua morte. O primeiro motivo da conversão de Nabucodonosor II foi a da interpretação decifrada de seus enigmáticos sonhos por um profeta hebreu chamado Daniel, que se torna, por ordem do Rei, governador da Babilônia. O mesmo trajeto espiritual realizado por Evil, filho de Nabucodonosor II, sendo o profeta seu conselheiro pessoal e assessor majoritário.

A exuberante cidade babilônica, ornamentada pelos famosos jardins suspensos, fora exterminada pelo Exército assírio comandada pelo Rei Ciro e seu assessor, Dario. Nos mesmos moldes da destruição da Babilônia, Nabucodonosor manda incendiar o primeiro templo de Salomão, três séculos e meio após a glória salomônica e meio século depois da derrota dos mesopotâmicos terem sido eliminados pelos persas. Período importante pelo fato de o Rei persa Ciro ordenar aos hebreus o retorno a Israel. Ele toma esta atitude, porque era a maneira mais lógica de povoar a Região desértica que separava o Mediterrâneo, estendendo o poderio do Império persa até a Grécia. Os exilados hebreus pensavam unicamente na milagrosa volta ao passado, embora netos dos que tinham deixado outrora Canaã! 
Premissa final: Os judeus têm peculiaridade incrivel de transformar tanta dor sofrida em inúmeras outras criatividades, porque além de capacitados e criativos em resolução de conflitos humanos são persistentes e empenhados na virtude da Fé, comungada com o Pai Criador. Homens que de tanto conquistar foram conquistados ... mas venceram!

\section{Cristianismo}

Na História das Religiões, o Império romano adotou o Cristianismo como Religião oficial no século IV, demarcando longo período de total desolação, século apontado em que o Judaísmo mesclado aos cultos do Paganismo sofre serí́ssimos ataques na intolerância religiosa, característica do poder estatal em vigor. Na polêmica Cristianismo-Judaísmo, vasto material documental oriundo desde as primeiras literaturas cristãs, sendo o século IV decisivo a todo perfil de agressividades; dentre eles, incêndios às sinagogas e ataques físicos aos judeus; entretanto, a Fé judaica nunca colocou ênfase especial na conversão dos novos fiéis.

O Paganismo, entretanto, não desaparece totalmente e tolerado em certos Reinos da Antiguidade. Por outro ângulo, o Judaísmo se baseia nas palavras da Bíblia hebraica, especialmente nas lições da Thorah, nome dado a seus primeiros cinco livros e por muitos anos profetas, rabinos e líderes espirituais acrescentaram apêndices de comentários à Thorah, em conjunto de série de interpretações dos próprios comentários no Livro Sagrado. Esses textos são a fonte de conselhos em autoridade moral, vasta gama de intrigantes situações, cuja complexidade pode, inclusive, intimidar leigos, porque a verdadeira essência da Thorah se resume em uma frase: "Aquilo que te é odioso, não o pratique contra o teu vizinho”.

O Cristianismo, Religião dos seguidores de Jesus Cristo, em desacordo ao Judaísmo, acredita que Jesus é o filho de Deus e o Messias, vinda prometida desde o Velho Testamento da Bíblia cristã e sustenta que a Humanidade vivia em pecado, desde então.

Jesus não é um personagem mitológico, homem mais importante da História da Humanidade teve vida real, em casa real e num lugar real. Se não houvesse a sua morte e a crucificação, o Cristianismo não teria existido. Jesus de Nazaré teve enorme família e muitos irmãos. Em sua trajetória, mister registrar a presença de duas mulheres vinculadas e destaque em sua Vida: Míriam de Magdala, Maria Madalena, que o acompanhou até a Sua condenação, abandonando, inclusive, a família dela no intuito de progressão espiritual e propósitos cristãos. E a imperatriz Helena, mãe do imperador Constantino; inconformada com o destino do nazareno, ela visitou, aos 70 anos, Jerusalém, ordenou a construção de templos cristãos no Oriente Médio, além de influenciar o filho imperador à 
conversão, advindo o Cristianismo romano oficial no Império, tornando Constantinopla a capital mais sagrada da História da Religião daqueles tempos.

A busca pelo DNA de Jesus ou a sua genealogia é incansável até os dias modernos, por meio do Sudário, incluso o de Turim (Itália) ou de seus próximos; por ter ressuscitado, seus ossos inexistem. Mas, em Israel, pretensos ossos de João Batista filho de Isabel, prima da Mãe Maria - têm sido estudados por cientistas na comprovação da autenticidade, achados em catacumba de antiga Igreja de Sazgrel, Bulgária, e sendo a primeira vez que relíquia religiosa desse teor é pesquisada pelos historiadorespesquisadores e arqueólogos, os quais extraíram minúsculas amostras ósseas, para análise da datação carbônica. Infelizmente, resultado negativo, dada contaminação das amostras extraídas. Todavia, dos DNAs dos sudários, com o propósito de que primos de segundo grau compartilham o mesmo DNA, chegaram conclusivamente aos habitantes da cidade de Nazaré. Por meio de autorização de alguns nazarenos - membros moradores deste local -, concluíram que o DNA de Jesus Cristo possui genes de uma comunidade de 3,5 mil anos, oriunda do Egito: os drusos.

A Religião drusa ainda existe! Eles creem na vida após a morte e na reencarnação semelhantemente aos modernos ensinamentos de Allan Kardec. Não há permissão para se poder integrá-la, porque se faz necessário ser descendente direto dos drusos, retificado até hoje; por isso, se trata de pequena e restrita comunidade religiosa. Daí a compreensão do porquê o ponto de interrogação move a Humanidade e o da Bíblia ser um portal para se conhecer o Mundo!

No ano de 1945, no Egito, um pastor encontrou um jarro confeccionado de pura cerâmica em gruta localizada próxima a sua aldeia; ao abri-lo, encontrou vários tabloides de papel escritos em idioma que ele não compreendia. As folhas dos documentos se encontravam envelhecidas e amareladas, servidas ao pastor para alimentar o forno de sua casa; porém, das restantes, um religioso vizinho tratou de comprá-las e expô-las à venda em mercado de antiguidades. Por sorte, um funcionário do Governo egípcio as resgatou e, mais tarde, se descobriu que elas eram um tesouro de valor incomensurável: a Coleção de Nag Hammadi, composta de treze livros de 1.600 anos, cujo conteúdo histórico a Igreja cristã evitou abafar durante todo esse período.

Os tabloides sobreviveram tanto tempo à censura religiosa, e se tornaram o maior e mais importante acervo de evangelhos apócrifos, sendo a sua literatura a que mais auxiliou sobre as origens do Cristianismo. A literatura do Nag Hammadi foi produzida entre os séculos I e III e os autores integram parte das primeiras comunidades cristãs; nesse acervo, a identificação de livros com depoimentos importantes que ficaram fora do Novo Testamento, tais como os evangelhos de Tomé e Tiago, os quais contradizem totalmente o do apresentado na Bíblia cristã. Dentre as narrativas, a de que "Jesus Cristo 
tinha virtude humana de alta sensibilidade", "Maria Madalena (Míriam de Magdala), uma lider autêntica", "Deus é um princípio masculino e feminino".

Não havia, naquele período, um cânone, nome dado ao conjunto oficial que compõem a Bíblia cristã; todavia, vários textos, cada qual narrado por diferentes seitas existentes, as quais registravam os próprios valores e crenças, abordando a origem do Mundo e da Vida como, também, sobre Deus e o Messias. Havia divergências, como as de origem dos docetas, que negavam a realidade material de Jesus Cristo, o consideravam portador de corpo etéreo e que, por isso, não nasceu nem foi morto na cruz e muito menos ressuscitou; os ebionitas, defendiam que Jesus tinha nascido de forma natural e que só depois de ter sido batizado, Deus decidiu adotá-lo; os ofitas, acreditavam que Caim era o mais importante representante espiritual do Mundo e a morte de Jesus é resultado de um crime do Universo, porém evento necessário para a salvação da Humanidade.

De todos os grupos mais importantes do Cristianismo primitivo, apontase os gnósticos que adotavam vida ascética, negavam a Matéria e acreditavam que o conhecimento era o caminho da salvação; algumas facções defendiam que Deus possuía princípio masculino e feminino; e de fato as mulheres desses grupos atuavam como mestras, líderes e profetisas. Uma ideia ainda hoje revolucionária para a Igreja cristã.

Não se olvida que Cristianismo, Judaísmo e Islamismo, monoteístas, vieram de parte da Mitologia palestina (Anônimo, 1988 - I.29-38; 12-13; Lara Peinado; XXVIII-XXIX, 183), selecionando distintas divindades assimiladas e amalgamadas em Javé (Moisés, 1985 - 27 e 21-22; 33 e 34; 1.1. 26-32) Eli (Mateus, 1985 - 27,46; 1.893) e Allah (Mahommed, 2001 - 2213; 55; 30, 30-493) como Religiões do Mundo.

A Legislação eclesiástica deste século limitava contatos entre cristãos e judeus e a Legislação dos imperadores romanos representava desconforto de compromisso, uma vez serem eles mesmos governantes cristãos entre a manutenção das Leis e da Ordem junto às concessões aos pedidos dos cristãos. Os textos legislativos revestidos de linguagem severa eram utilizados pelos oradores romanos cristãos e aos poucos se tornando discriminatórios, assimilando duras penas. Como exemplo, eram condenados à morte senhores judeus que convertessem as suas mulheres e seus escravos judeus. O Clero judeu estava submetido à carga da decúria (ofício municipal), do qual estava totalmente isento o Clero cristão. Já o casamento entre cristãos e judeus era considerado sumariamente adúltero.

9. Islamismo

Os seus seguidores são intitulados muçulmanos, cuja crença se exprime na fórmula denominada chahada ou profissão de Fé:

"Só há um Deus e Maomé é o seu profeta" 
Acreditam em Juízo final e na vida após a morte, tanto no Céu quanto no Inferno; seguem a orientação espiritual do sagrado Alcorão e dos hadiths, palavras e atos de Mahommed e seus fiéis companheiros. A palavra sagrada islã significa "submissão", porque a Religião envolve submissão incondicional à vontade de Deus, conhecido por eles como Allah.

Após a Fé revelada a Mahommed, o Islamismo se difundiu como relâmpago pelo Oriente Médio e Norte africano. Cumpre salientar que o Oriente Médio é o centro do Mundo islâmico e essa Fé predomina em todos os países da Região, exceto Israel. O perfil característico dos muçulmanos é o de que todos se voltem para Meca ao rezar e esperem visitá-la pelo menos uma vez na passagem desta vida. Existem muçulmanos, além do Norte africano, em países da Ásia, a bela Indonésia e se estima em consonância à atividade missionária e ao crescimento da população mundial que atualmente a Religião islâmica açambarca cerca de 2,5 bilhões de fiéis no Mundo moderno.

Os muçulmanos acreditam que o Islã sempre existiu como modus vivendi e que nosso Deus destinou-o à Humanidade, além de o Pai Todo-Poderoso ter enviado série de profetas - como Moisés - para atrair os homens à verdadeira Fé, culminando com Mahommed, o mensageiro Dele. A Fé islâmica foi revelada a Mahommed (570-632) no século VII d.C., em Meca (atualmente Arábia Saudita), onde nasceu, cidade comercial florescente e importante centro religioso, tendo no centro a Caaba, santuário que abrigava estátuas de deuses e deusas tribais venerados pelos árabes, além de um meteorito sagrado de cor brilhante enegrecida, abrigado em vidro de alta resistência. O santuário Caaba ainda existe e pode ser visitado tanto por muçulmanos quanto não-muçulmanos.

Aos 40 anos de idade, Mahommed se sentiu chocado e constrangido com a variedade de deuses venerados, época em que costumava ir ao Monte Hira, localizado nos arredores de Meca, para meditar sobre a Natureza divina. Nesse aconchego, recebeu em final de tarde ensolarada a Revelação de Deus, por meio do Anjo Jibril, Gabriel, cujo conteúdo das revelações mais tarde coligidas no Qu'aran (Alcorão). Homem de pura filosofia assimilada sobre a Natureza do Mundo, órfão de pai e mãe, criado pelo avô e tio, além de belo semblante masculino, guerreiro e trabalhador na função de mercador; por isso, contratado por uma viúva, Kadhija, para conduzir caravanas através da Península arábica.

Nessas viagens, conheceu pessoas que acreditavam em um Deus Único, contrastando à maioria dos habitantes da Arábia, politeístas. Casou-se com a viúva e se tornou pai de quatro filhos. Mahommed era amado por todos que o conheciam, pregava a crença em Allah, o que fez entrar em conflito com líderes religiosos locais e, nesse contexto, abandona a cidade, em 622, migrando-se para Medina - outrora chamada Yathrib -, decisão conhecida como Hegira, marcando, assim, o início do calendário islâmico. Em Medina, converteu grande parte da população ao Islamismo e se tornou o líder de 
comunidade muçulmana organizada, embora ainda houvesse oposição a Mahommed em Meca, o que o levou a sangrenta batalha entre as duas cidades, período em que invade Meca, em 630, ocupa a Caaba e remove as estátuas dos antigos deuses. Em 632, a sua influência se espalha por toda a Península arábica e encetou peregrinação anual à Caaba (Ramadã), em Meca, reservada exclusivamente aos muçulmanos.

No décimo dia da peregrinação pregou o último Sermão, no qual instava muçulmanos a se tratarem entre si como irmãos e a manter a unidade do Islã. Avisado pelo Anjo Jibril (Gabriel) de que iria se tornar o Mensageiro de Deus, segundo a tradição, foi conduzido pelo Anjo até Jerusalém, local de sua ascensão ao Céu, ou Mi'raj, a partir de uma rocha do templo, onde mais tarde se construiu a Cúpula do Rochedo, lembrando que Deus lhe dera instrução sobre as preces diárias e a prática religiosa. Ele morreu nos braços de sua mulher favorita, a bela Aicha. Uma mesquita em Medina foi reconstruída para abrigar o seu túmulo.

A comunidade do islã é chamada umma; originalmente os árabes tinham prioridades no interior da umma, porque Mahommed era considerado o profeta da Nação árabe; todavia, com a difusão do Islã passou a se referir a todos os muçulmanos sem restrição de etnia, nacionalidade e ideologia, uma vez a umma garantir unidade religiosa, mediante desafios que a secularização propõe ao Islã tradicional. Os califas lideraram o Mundo islâmico depois da morte de Mahommed; o primeiro foi Abu Bakr, pai de Aicha, a segunda esposa do profeta. Ele era chamado Al Sadiq, "o verdadeiro", seguiram-no Umar, Uthman e Ali, que era primo do profeta e seu afilhado.

Finalmente, cita-se que $90 \%$ dos muçulmanos são sunitas, corrente principal do Islã. O nome sunita se originou da palavra suna ou caminho que, por sua vez, a doutrina de Mahommed é implícita em suas palavras e atos. O xiismo também é uma das principais correntes; o nome deriva da palavra árabe sh'at, significado de "partido de Allah". Os xiitas acreditam que Ali e seus descendentes foram os verdadeiros líderes da comunidade islâmica e dão ênfase ao sofrimento, sendo o filho de Ali, Hussein, venerado por seu martírio em Karbala, em 680 d.C.; os xiitas criaram o próprio sistema de Leis, são maioria no Irã e no Sul do Iraque. A consciência xiita mais radical foi despertada pela Revolução iraniana. Entretanto, há diversos grupos dentro do Islamismo xiita, alguns surgiram a partir de seita chamada ismaelismo que incluem drusos do Líbano e nizaristas, grupo amplo liderado pelo Aga Khan.

A corrente mística do islã é chamada de sufismo e os sufistas enfatizam uma relação pessoal com Deus a par da observância de Sua Lei; praticam rituais que envolvem música, canto, dança e exercícios de respiração para se atingir um estado místico. O sufismo exalta as virtudes da Humanidade e do auxílio ao próximo, também é organizado em diversas ordens e cada qual com um líder espiritual chamado shaykh. Essas ordens têm seguidores leigos e membros efetivos conhecidos como faquires ou dervixes. 
10. Hinduísmo

Uma das mais tradicionais e milenares na História das Religiões é o Hinduísmo, da Índia; seus seguidores, os hindus, mantêm crenças distintas, baseadas na ideia de a vida na Terra ser parte de ciclo eterno de nascimento, morte e renascimento. Para eles, nascemos e reencarnamos sucessivamente; porém, se se levar a vida dirigida ao Bem, pode-se, por fim, atingir a finitude, libertação desse ciclo, pensamento assemelhado à Filosofia Espírita moderna; exceção, a existência no cerne do Hinduísmo das centenas de deuses: dois deles, Vishnu, o Protetor, e Shiva, o Destruidor, se destacam pela popularidade.

Por volta de 2000 a.C., a Índia foi invadida pelos arianos, originários das estepes da Ásia Central. Esses invasores trouxeram consigo série de hinos, os Vedas, transcritos mais tarde, dando margem à classificação dos deuses védicos que se tornaram as mais antigas divindades conhecidas no universo hinduísta, lembrando que há cerca de 3.500 anos, a comunidade da Região do Vale do Indo - atual Norte da Índia - começou uma organização de sistemas religiosos mais antigos da História da Religião.

Essas crenças, açambarcadas e reunidas como Hinduísmo, foram transmitidas, oralmente, de geração em geração por séculos até serem transcritas nos Vedas - que nada mais são que a compilação de hinos e preces -, considerados o primeiro Livro Sagrado da História da Humanidade, conteúdo composto por quatro volumes de textos em versos, explicando, concomitantemente, a unidade e a variedade das múltiplas correntes, classificadas pioneiras da Religião Primeva.

E graças aos seus ensinamentos, esse conjunto de Livros é considerado sagrado para mais de 1,5 bilhão de seguidores que formam seitas diferentes, a ponto de serem classificados como monoteístas e politeístas ou, ainda, panteístas e integrantes de uma mesma Religião. Cumpre salientar que a primeira versão dos Vedas, em papel impresso, seja do século II a.C., período em que o povo hindu desenvolveu sistema de escrita que, segundo a lenda, teriam sido organizados por Vyasa, sábio e encarnação de Vishnu, deus que nos ciclos da Criação e Destruição do Universo elabora as escrituras em quatro Livros, no intuito de garantir que os cânticos se propagassem e se tornassem eternizados.

Além disso, o mesmo Vyasa seria o responsável por outros textos sagrados do Hinduísmo, o Mahabharata, ditado por ele a Ganesh, o deus com cabeça de elefante que teria passado as palavras para o papel. A série de deuses e deusas do Hinduísmo é imensa; todavia, no interior dessa diversidade existe também unidade, pois todos os deuses e toda a Criação faz parte de um Ser universal e absoluto intitulado Brahman. Entre os muitos deuses, três figuras se destacam: Brahma (o Criador), Shiva (o Destruidor) e Vishnu (o Protetor). 
Neste século XXI, há mais de 900 milhões de hindus no Mundo, a maioria vivendo no subcontinente indiano, número que ainda está aumentando, principalmente devido ao constante crescimento da população da Índia. Grande parte dos hindus são vegetarianos, devido à crença na reencarnação e da convicção de que todos os seres vivos são parte do mesmo Espírito; eles acreditam que animais e seres humanos devem ser tratados com igual respeito e reverência. Levar uma vida pacifica, estudar os textos antigos do Hinduísmo, rezar e meditar são os meios utilizados pelos hindus para atingir seu objetivo; finalmente poder se identificar com Brahman ou Deus! ${ }^{8}$

\section{Budismo, Confucionismo, Taoismo, Xintoismo}

Ao se fazer análise minuciosa sobre Budismo, a premissa final é a de que a sua classificação, Religião budista, na verdade se trata de ideologia espiritual, uma vez Buda não ser um deus e sim guia espiritual, lembrando que o culto budista - ao inverso de seguidores de outras comunidades religiosas venerar deuses - implica prestar homenagem ao seu idealizador. Todavia, eles também têm o direito de seguir outras Religiões e viver de acordo com os preceitos budistas.

Aos budistas, a meta importante é a de observar os Oito Caminhos, significado da compreensão plena às verdades filosóficas como, também, o de se evitar ações que prejudiquem semelhantes e o de se levar vida correta, por meio do trabalho e estudo. De maneira que, agindo assim, encontra-se uma fórmula de alcançar reencarnação favorável mais amena, incluso a de se atingir a iluminação, estado de pureza espiritual, completamente livre das preocupações mundanas do ciclo da vida.

O fundador, nascido sob o nome de Sidarta Gautama, viveu no século VI a.C., em família indiana de elevada posição social. Ao ensinar as Quatro Nobres Verdades e os Oito Caminhos que combinam ensinamento moral com regras básicas de meditação e concentração, se torna futuro líder de seu povo, embora tenha vivido em luxúria e riqueza.

\footnotetext{
8 Apesar de terem poucos adeptos, em parâmetro ao Hinduísmo, o Jainismo e o Sikhismo são Religiões importantes na Índia. O Jainismo, com cerca de mais de cinco milhões de fiéis, se concentra sobretudo no Norte e no Oeste do país indiano. O Sikhismo se originou no Pendjab, onde vive a maioria dos quase três milhões de sikhs do Mundo. Ambos os credos procuram libertar os fiéis do ciclo da reencarnação, mas em outros aspectos suas concepções são muito distintas. No Jainismo, não há um deus supremo Criador; os jainistas seguem a orientação de guias espirituais chamados jinas e uma das mais importantes doutrinas desses mestres é a da não-violência, ou "ahimsa". Esta se revelou uma das ideias mais influentes e significativas do moderno pensamento indiano. Os adeptos do Sikhismo acreditam em um Deus Único, são minoria numa Índia predominantemente hindu e por várias vezes sua Fé sofreu perseguições. Por esse motivo, os sikhs desenvolveram forte senso comunitário e sustentam o direito de pegar em armas para defender a si próprios e a seu povo. Eles se empenham em compreender os hábitos alheios e em ajudar a qualquer pessoa necessitada.
} 
Mas abandonou tudo isso para seguir vida religiosa em busca da iluminação, a fim de se libertar do ciclo da morte e da reencarnação.

Sidarta era filho de Suddhodana, rajá (líder local) que pertencia ao Império shakya, no Nordeste da Índia e membro do xátria, classe de guerreiros hindus, caminho seguido por seu filho, Buda; todavia, seu pai o mantinha confinado no palácio e portanto não tinha ideia nem experiência do sofrimento humano fora dos portões. Assíduo leitor de temas sobre diversas curiosidades da Natureza do Mundo e da vivência dos seres humanos ateve-se à vida após a morte, motivado após o falecimento da Rainha Maya, sua mãe. Nesse tempo conseguiu a permissão do pai para viajar. Jovem, se sentiu profundamente chocado ao conhecer três aspectos do sofrimento humano: a doença, a velhice e a morte. Abalado, Sidarta viajou pela quarta vez, conhecendo um asceta andarilho, convicto do ciclo da vida, inspirando-o a uma vida asceta e nova em busca da verdade e da iluminação.

Com o passar dos anos, realizou profunda meditação sob árvore da espécie bodhi, atingindo um estado em que o modo do sofrimento ou da morte não mais o afetaria, tornando-se iluminado: o Buda! O seu primeiro sermão aconteceu em Varanasi, instando ouvintes a segui-lo: o "caminho do meio" pelo qual se evita os extremos. Ele morreu aos 80 anos, eliminando apego às coisas terrenas e o medo da dor, alcançando o parinirvana ou simplesmente nirvana final, superando o ciclo de morte e reencarnação. O nirvana significa, "esfriar" no sentido de que as chamas do engano da cobiça, da ganância e do ódio foram apagadas como, também, uma luta à libertação do samsara. Nos mesmos moldes de outras Religiões indianas, o Budismo encara a vida como parte de um ciclo infinito de nascimento, morte e reencarnação chamado samsara ou "vaguear infinito" e todas as coisas vivas são parte desse ciclo; só se livra dele ao atingir o nirvana. ${ }^{9}$

O Budismo tem longa história na China, vasto território asiático de tradição milenar religiosa, além das Religiões nativas mais conhecidas: Confucionismo, nome derivado do fundador, Confúcio (551-479 a.C.) e o Taoismo. Dada proximidade geográfica, China/Japão, em contínuo contato, o maior dos dois países influenciou o Japão de maneira permanente e duradoura, enfatizando a Religião. Das três grandes Religiões ou "caminhos" da China - Confucionismo, Budismo e Taoismo -, as duas primeiras foram importadas ao Japão, por meio de mercadores e missionários.

Mas o Japão também tem sua própria Religião nativa: o Xintoísmo, adeptos que acreditam em legião de Espíritos portadores de forças da Natureza e muitos dos japoneses abraçam essa Fé, trazida de além-mar às terras japonesas. Por exemplo, os

$9 \quad$ Os budistas seguem os seus líderes mestres que difundiram essas ideias em toda Ásia e mais além. Existem hoje mais de 500 milhões de budistas em todo o Mundo, a maioria no Nordeste asiático - China, Tibete e Japão - quanto no Sudeste do continente (Sri Lanka, Camboja e Tailândia). Embora a maioria viva na Ásia, a Religião se espalhou pelos quatro cantos do planeta, incluso Brasil. 
samurais - que significa "aquele que serve" ou "servidor do imperador" - lendários guerreiros, membros da casta militar a serviço de um daimio (daimio = designação comum aos príncipes que perderam os seus privilégios na Revolução de 1868) muitos deles pertencentes à nobreza/elite japonesas; o caminho de um samurai era o da morte com honra em treinamentos da arte marcial, assimilada mais tarde por outros países.

\{Por meio dos missionários portugueses e espanhóis, o Cristianismo não logrou êxito na China e no Japão, perseguidos e expulsos; nas tentativas continuadas, muitos deles foram condenados à morte e queimados vivos em cenas de horror, às vistas de padres missionários.\}

O Confucionismo nasceu da ideologia do sábio K’ong-fou-tseu (551-479 a.C.), conhecido no Ocidente como Confúcio, consideradas as ideias mais importantes do pensamento e formação jurídica da China. Confúcio não pretendia como Buda fundar uma Religião; seu propósito era o de propiciar instrução moral e a ensinar as pessoas a viver bem, em consonância aos valores do viver, da cortesia, sabedoria e generosidade; dentre as ideias, a destinada aos filhos na honra e respeito aos pais tanto em vida quanto após a morte. E por isso, encorajava a prática do culto aos antepassados que, atualmente, integra parte da Religião chinesa. Notórios foram os sábios posteriores: Mêncio (372-280 a.C.) e Zhu Xi (1130-1200) que transformaram as ideias de Confúcio em um sistema religioso, influenciando fortemente o Direito chinês, inclusive o moderno.

O Taoismo é composto por adeptos que buscam um caminho espiritual, o Tao, formulado por antigos pensadores chineses; todavia, o Tao é mais do que um caminho: é definido como a fonte de tudo o que existe neste minúsculo planeta. Ao seguir o caminho, os taoistas aspiram a união com o Tao; logo, com as forças da Natureza, implica em se livrar da preocupação e desapego ao Mundo Material; aliás, ensinamento ao procedimento da conduta editada por Gautama Sidarta. Ao se encontrar o caminho também se alcança o equilíbrio e a harmonia na própria vida pessoal e a conquista da paz, oriunda da compreensão de tudo o que existe ao redor.

Os taoistas asseveram que os que atingem esse objetivo espiritual serão imortais, após a morte física e os modernos pensadores distinguem três formas desse credo estreitamente ligados:

- o taoismo religioso que envolve a busca do Tao;

- o culto das divindades; e

- o Taoismo como complexo modo de vida, o que inclui ideias tradicionais sobre saúde, meditação e exercícios físicos.

Os mais importantes textos taoistas são o Tao Te King, que teria sido escrito por Lao Tsé, e o Tchung-Tseu, que leva o nome de seu Autor. O Tao Te King é um texto político que prega o Tao aos governantes, no intuito de ensinamento à sabedoria; por outro lado, o Tchung-Tseu apresenta filosofia de vida às pessoas comuns. 
Apontado acima, o Xintoismo é nome da mais antiga Religião Primeva nativa japonesa, cujo significado é “caminho dos deuses”, recebendo esse nome no século VI d.C., para se distinguir do Budismo e no âmbito religioso estão seres divinos ou forças da Natureza chamados kamis, cultuados em lares particulares ou em santuários públicos; existem centenas de santuários, desde os de estaturas enormes de Ise e Izumo, conhecidos e reverenciados nacionalmente, até aos menores encontrados em todas as localidades urbanas e rurais do Japão, a terra do Sol nascente.

\section{Religião Espírita}

O Vocabulaire Technique et Critique de la Philosophie, de André Lalande, ao consignar a Filosofia Espírita com a denominação de Espiritismo, acentua o seu caráter espiritualista; a seguir, ao tratar de termo spiritualisme, esclarece que é impróprio se denominar o Espiritismo de Espiritualismo como o fizeram ingleses e, por vezes, os alemães. Por quê? Porque o Espiritismo é apenas espécie do gênero Espiritualismo assim como o Marxismo é apenas do gênero Materialista.

O Livro dos Espíritos, de Allan Kardec, é a primeira obra espírita, publicado no século XIX, considerada a primeira codificação do Espiritismo e o primeiro precursor do Espiritismo na modernidade é Emmanuel Swedenborg, nascido, em 1688, em Estocolmo e desencarnado em Londres, 1771. Ele escreveu dezenas de obras, médium de extraordinária capacidade; dentre elas, a da vidência, deixando um legado de inúmeros ensinamentos assemelhados às ideias preconizadas pelo Espiritismo: imortalidade da alma, possibilidade do intercâmbio mediúnico, Perispírito e a descrição minuciosa de realidades do plano espiritual como, também, Swedenborg foi o primeiro estudioso a se debruçar sobre os fenômenos mediúnicos e a aceitá-los. Na época medieval, século XVI, registro da vidência do francês Michel de Nostredame, alcunha Nostradamus, e na moderna da respeitável profetisa cega búlgara, Baba Vanga; ambos portadores de mediunidade e sensibilidade extraordinárias, incomuns. Mas um terceiro dos EUA é classificado como o mais respeitado da época moderna: Edgard Cayce, portador de previsões mediúnicas extraordinariamente corretas: todas acontecidas.

Mister não olvidar Andrew Jackson Davis, dos EUA, nascido em 1826 e desencarnado em 1910, possuidor de elevada capacidade mediúnica que se torna o pioneiro na descrição da vida espiritual, prevendo acontecimentos como os de Hydesville ${ }^{10}$ e o do

10 Hydesville era uma pequena aldeia dos EUA quando, em março de 1848, foi palco dos primeiros fenômenos mediúnicos dos tempos modernos, representando os fatos prelúdio do advento da Doutrina Espírita consumados pela codificação de Allan Kardec. As casas eram na maioria feitas de madeira e em uma delas residia a família de John Fox, pai de muitos filhos; dentre eles, duas meninas Margareth, de 14 anos, e Kate, de 11 anos. Após a família ter se transferido para o local em 11 de dezembro de 1847, seus membros 
advento do Espiritismo, sendo homem de destaque em período anterior à codificação da Doutrina Espírita. O Espiritismo é uma Filosofia Espiritualista e a codificação da Doutrina Espírita fez com que seu Autor o professor Hippolyte Léon Denizard Rivail, ainda sem a alcunha de Allan Kardec, criasse vocábulos como Espiritismo para designar a doutrina propriamente dita e Espírita ou Espiritualista na identificação de adeptos do Espiritismo.

Espiritualista é aquele que acredita haver em si algo mais do que a matéria, uma vez o Espiritualismo ser o oposto de Materialismo e o Espiritismo é Ciência, Filosofia e Religião que não surgiu para contestar, combater ou destruir as demais Religiões; todavia, para ajudá-las, na comprovação da imortalidade da Alma.

Nas décadas de 1850-60 surge na França um fenômeno que toma vulto e objeto de atenção, cuja manifestação alcança outros países como EUA e Suécia: as mesasgirantes. Inicialmente o fenômeno surge por meio de móveis - mesas, principalmente, e de cadeiras -, que se movimentavam repentinamente sem causa alguma aparente a lhes impulsionar ou sustentar tais movimentos. Em larga escala, esses fenômenos passam a ser observados nos salões parisienses que, em curto espaço de tempo, se descobre a possibilidade de se entravar comunicação inteligente, com tais objetos. Os fenômenos atraem fortemente a atenção mundial, tendo sido as mesas-girantes motivo das mais variadas posições ao seu respeito: charlatanismo para uns, efeitos de causa física ou psíquica para outros, intervenção de mortos e atuação demoníaca para incrédulos.

Todavia, com o passar dos tempos, as mesas-que-giravam e que se comunicavam tornam-se popularizadas e asseguram prestações das mais diversas funções ao público que as presenciava, como objetos de diversão, conselheiras de eventuais problemas, adivinhadores de sorte e de futuro, acompanhamentos de números musicais, serviçais em trabalhos dos mais variados tipos e até mesmo - relatado em jornais parisienses, como o L'illustration - testemunhas de crime consumado em suas presenças.

Finalmente, em 1854, Allan Kardec toma contato com o famoso fenômeno das mesas-girantes com a intervenção do senhor Fortier, em Paris. Sem dar crédito prévio, frequenta as sessões na casa da senhora Plaine (a Maison Plaine), nas sessões da mansão do senhor Baudin (junto às suas filhas Julie, de 14 anos e Caroline Baudin, de 18 anos)

passaram a ouvir ruídos nas paredes, arranhões na madeira de construção e nos móveis e assoalhos, vibradas no forro, vidros das janelas estilhaçando, preocupando-os intensamente. As duas meninas menores criam um método de se comunicar com pretensas entidades espirituais, sendo o método o de bater palmas repetidamente, com resultados diferentes até então. Do sistema rudimentar, se descobre que o Espírito comunicante era um vendedor chamado Charles Rosna que havia desaparecido há muitos anos. Ele havia sido assassinado na própria casa. Autoridades do local, mediante as informações mediúnicas trataram de escavar o solo, em 1848; todavia, somente em 22 de novembro de 1904 com a queda de uma parede, verificou-se a existência de um esqueleto emparedado junto a um baú que pertencia ao mascate. Margareth e Kate, posteriormente, foram consideradas médiuns que inconscientes e involuntariamente agiam, mediante intervenção, na produção dos fenômenos. Fatos e métodos são catalogados na História da Filosofia Espírita. 
como, também, na do senhor Roustan; na posição de médium, toma parte a senhorita Ruth Japhet, de 20 anos, posteriormente aclamada como uma das mulheres mais sensitivas do Espiritismo.

Ao redor de uma mesa vazia redonda, as filhas do senhor Baudin principalmente a de 14 anos, Julie -, utilizam uma cesta contendo um lápis encaixado na borda, o objeto desenha letras em espiral que aos poucos resulta em palavras, analisadas atentamente por todos os presentes; as mãos delas desenham no papel série de frases; pouco meses depois, auxiliam a fundação de uma Religião: o Espiritismo. Em cerca de vinte meses, o professor Allan Kardec organiza e coordena, ao longo das reuniões, 501 perguntas e respostas vindas dos Espíritos sobre o Universo, em saldo positivo do Mundo do Espiritismo. Uma Doutrina sobre o Mundo Invisível existente ... e muito mais do que uma diversão da burguesia parisiense.

O poeta Victor Hugo era exímio frequentador das reuniões, manifestandose em jornais que "negar a atenção a que tem direito o Espiritismo é desviar a atenção da Verdade”. Os princípios básicos da Doutrina Espírita são: a existência de Deus; a pluralidade das existências; a preexistência e persistência eterna do Espírito; a intercomunicação entre encarnados e desencarnados; as recompensas e perdas, consequências naturais dos atos praticados; progresso infinito, por meio de comunicação universal entre os seres humanos. A ascendência do Espiritismo é oriunda do Druidismo, sistema religioso coordenado pelos druidas, sacerdotes gauleses e bretões. Os adeptos do Druidismo foram ancestrais de extrema inteligência e pioneiros na História da Humanidade e das Religiões a se pronunciarem, por meio da manifestação mediúnica, comprovado, inclusive, cientificamente.

II. As influências religiosas nos principais ordenamentos jurídicos

1. Introdução

A ordem universal apresenta-se mesclada à desordem, uma vez que nem tudo é ordem no Universo; a desordem também existe no comportamento desregrado, na injustiça, no sofrimento ou na dor e de conhecimento geral da Humanidade, são fatos reais; todavia, fatos contrários ao que se considera ordem como, por exemplo, a falta de compaixão em mentes inteligentes acarreta comportamento de alta periculosidade e ingrediente à realização de ideias sinistras. As assertivas servem ao cômputo de que a formação do planeta, por meio de asteroides em infinitas colisões, produzem energia e a estabilidade da Terra, incluso nos presenteando com elemento vital, água, origem da Vida, pois a ordem não existia. 
O homem primitivo desconhecedor da ordem lutava à sua sobrevivência; desconhecia o direito do semelhante e muito menos o valor do nascimento. Da agregação e aprendizagem coletiva, por ser o homem ser gregário por excelência, a evolução agrícola - pelo raciocínio lógico, ímpar e criativo do plantio do trigo, cevada e cebola junto à linguagem universal proto-hindu-europeia. Assinala-se também que animais eram abatidos à alimentação indiscriminadamente, advindo na jornada da sobrevivência a ideia virtuosa em respeitá-los, enfatizando cavalos e camelos que passam a auxiliá-los, nesta primitiva mas eficaz evolução, iniciada há milhares de anos na África setentrional e a se espalhar por toda a Europa e Ásia.

Assim, as primeiras civilizações traçam a linha reta e linear na História da Humanidade, lembrando que a busca por outros mundos habitados sempre existiu, iniciada pelos primeiros gregos astrônomos, conhecedores das constelações estelares, origem do minúsculo planeta que habitamos. Essas civilizações primitivas têm histórias contadas, repetidas e em evolução constante, por meio das gerações; mitos hoje conhecidos e que formam elo vivo com o surgimento da Terra e origem da Humanidade. Por toda parte da África, da Ásia, das Américas à Oceania, um sem-número de narradores transmitiu a seus descendentes lendas épicas sobre as grandes peripécias de deuses, deusas, heróis e seres sobrenaturais em tentativa de explicar a Criação e a Catástrofe: a Vida e a Morte. Para onde vamos após a Morte? ... Hinduísmo, Budismo, Espiritismo são algumas das correntes religiosas que tentam responder.

As Religiões Primevas eram voltadas ao Paganismo, uma vez o desconhecimento da existência do Deus Único trazida, segundo a História da Religião, pelos hebreus, orientados por Moisés e sua família ... muito tempo depois das Primevas.

\section{Judaísmo. Direito Talmúdico}

O Judaísmo surgiu por volta do século XIV, desenvolvendo-se como Religião monoteísta baseada no diálogo entre Deus (Javé) e seu Povo escolhido: os judeus; os patriarcas dessa Religião são antigos líderes em linhagem iniciada por Abraão, seu filho Isaac e seu neto Jacó (ou Israel), em feitos narrados no Gênesis ("Origem”), o primeiro Livro da Bíblia hebraica, a "Lei de Moisés" ou Pentateuco (em hebraico Chumash, Chamishá Chumshê Torá ou simplesmente Torá, conjunto dos cinco primeiros Livros da Bíblia hebraica). Cumpre salientar que os judeus se espalharam por todo o Mundo, mas totalmente unidos na sua cultura originária tanto na Lei quanto nos usos e costumes familiares.

Da longa jornada à libertação egípcia, espaço de tempo ao Diálogo DeusMoisés, o líder da Nação e um pacto ou aliança: o surgimento dos Dez Mandamentos, escritos com fogo em placas de tábuas de pedra, formando o Código de Conduta Moral 
e Religiosa. A Thorah constitui a Lei judaica, contendo 613 mandamentos (instruções diretas de Deus ao Povo de Israel). Os seus primeiros pergaminhos - por representar a Palavra Divina - são tão sagrados que ninguém pode tocá-los, além de só se poder desenrolá-los e vice-versa, segurados por meio de cabos de madeira de lei.

A interferência jurídica é composta pelo Direito Talmúdico, estrutura favorecida pela razão político-social, enfatizando o Direito de Família e mais recentemente os Direitos Humanos. Na Doutrina hebraica, o Direito é imutável e só Deus pode modificá-lo, ideias encontradas, também, no Direito Canônico e na Châr'ia muçulmana; os intérpretes, rabinos, podem interpretá-lo e adaptá-lo, conforme a evolução social mas nunca modificá-lo totalmente. Uma série de instituições jurídicas hebraicas sobreviveram no Direito medieval e mesmo no moderno, sobretudo pelo iter jurídico do Direito Canônico, uma vez a mesma fonte: a Bíblia, Livro que o Cristianismo denomina Livro do Antigo Testamento.

Talmude, do hebraico, significa ensinamentos; trata-se de compilação literária, redigida em idiomas hebraico e aramaico, que reúne debates e discussões dos antigos rabinos acerca de vasta gama de questões religiosas e sociais e existe em duas formas de compilação: Talmude Babilônico e Talmude Palestino. O Talmude se tornou a pedra fundamental do Judaísmo rabínico, sendo que sua autoridade sofreu ataques dos caraítas, cristãos e judeus reformados; todavia, ainda constitui a base das instruções na yeshivot (yeshivot se aproxima às normas do Direito Consuetudinário, isto é, usos e costumes de determinado povo ou comunidade).

Os primeiros indícios de sistematização normativo-jurídica dos judeus da Antiguidade foram do período em que estiveram sob o domínio babilônico e uma série de circunstâncias é aventada à condução de os judeus elaborarem um Direito avançado para a sua época, notabilizadas pela preocupação com a equidade, elemento psicológico desse Povo, crença e estudos, mais tarde cognominado Povo do Livro (a'm hasefer). Esse Povo do Oriente Médio, dedicado aos estudos e aos de reflexão, elaborou normas de caráter ético, religioso e social que foram inseridas na Thorah, por meio de rolos com textos de perfil sagrado, enfatizando os especiais, a Shabat.

As fontes do Direito hebraico são: a. a Bíblia, Lei Revelada por Deus (Gênese, Exxodo, Levítico, Números e o Deuteronômio, complemento dos quatro precedentes); posteriormente são incorporados os Profetas e os Hagiógrafos, usos, costumes e instituições. A interpretação conjunta dos rabinos na Palestina e na Babilônia, além dos comentários, são chamados Guémara, significado de ensino tradicional; logo se tornaram abundantes em parâmetro à Mishna o conjunto de comentários dos rabinos dos séculos III, IV e V d.C.; e novo esforço de sistematização foi criado, agrupando Mishna e Guémara no Talmude, isto é, os "novos estudos" em Jerusalém (350-400 a.C.) 
e na Babilônia (500 a.C.), aproximadamente na mesma época da grande codificação de Justiniano.

3. Hinduísmo. Direito hindu. Direito indiano

Desenvolvida ao longo de milênios, o Hinduísmo é a Religião principal da Índia, abrange campo complexo de tradição, crença religiosa, filosofia e mitologia. As raízes do Hinduísmo podem ser retraçadas até os arianos - oriundos das estepes da Ásia Central e descendentes dos árias que compunham antiga comunidade indo-europeia; dentre eles, os mongóis que invadiram a Índia, em 2000 a.C., munidos do seu panteão de deuses masculinos, no segundo milênio a.C. A civilização instalada no Vale do Rio Indo, atual Norte da Índia, tinha Religião centrada em cultos da fertilidade e em uma deusa-mãe. Os arianos adotaram muitas dessas crenças e deuses e deusas do Hinduísmo, notadamente Brahma (o Criador), Vishnu (o Preservador) e Shiva (o Destruidor); os três, aspectos de Brahman ("Deus"), o primeiro ou princípio eterno e uno.

Desenvolvido pela crença ao Hinduísmo, o Direito hindu é o Direito tradicional da Índia, aplicado pelos e adeptos da Religião em determinadas situações, enfatizando o Direito de Família, além de coexistente com o Direito indiano. Mas não se deve confundir hindu com indiano: os habitantes da Índia são os indianos; por outro lado, aqueles que adotam o Hinduísmo como Religião são os hindus. O Direito indiano se aplica a todo e qualquer dos seus habitantes, não importando qual seja a sua Religião, enquanto o Direito hindu é o Direito aplicado somente à comunidade hindu. A premissa final: o Hinduísmo, além da perseverança milenar, tem forte impacto na conduta dos adeptos.

O Hinduísmo se desenvolveu no decorrer dos últimos 4 mil anos, disseminado em todo território indiano e em alguns outros lugares do Mundo nãocatalogados estatisticamente. Possui grande variedade de seitas; porém, não há assinalado um fundador oficial como, também, um único conjunto de crenças, embora existam muitos deuses. Dentro dessa diversidade existe unidade, pois todos os deuses e toda criação fazem parte de um Ser Universal: Brahman, a realidade única e última para os hindus, descrito como a Força incognoscível; origem de toda a criação; Ser puro, deleite puro e inteligência pura. Não se olvida que os princípios gerais da Índia são extraídos dos Livros Sagrados, intitulados Shrutis que compreendem os Quatro Vedas e seis apêndices, Vedangas.

O Direito redigido é oriundo da época da dominação inglesa, quando juristas indianos e ingleses trataram da composição do Code of Civil Procedure, em 1881 como, também, do Indian Contract Act, 1892 e o Indian Registration Act, em 1908. A base hermenêutica jurídica tem total respaldo no Hinduísmo, a Religião. A ideia de Religião 
desvinculada do Direito ou, ainda, de uma Religião separada das outras regras de vida social não existe na tradição hindu.

Portanto, o Direito hindu é o Direito tradicional da Índia, aplicado aos adeptos do Hinduísmo, especificamente em determinadas situações e coexistindo com o Direito do Estado. A expressão Dharma - em exata definição - se aproxima do significado ou conceito de Direito; todavia, não tem o mesmo sentido, porque não reconhece direitos individuais, a não ser exclusivamente o de deveres e na Doutrina indiana moderna, o Dharma agrupa regras do Direito; a sua forma de expressão é bem diversa das dos direitos do Ocidente ou, ainda, da Châ'ria muçulmana. As prescrições de ordem ritual e de ordem jurídica, de acordo com René David "se misturam umas às outras nos dharmasastras". Dharmasastras é o nome de um Livro que contém preceitos ou normas de conduta religiosas, morais e jurídicas, ensinamentos dos sábios da tradição hindu chamados Smürti, dos quais os mais conhecidos são Manu, Yajnalkaya, Nihabandhas e Narada. Número significativo de regras que interessam ao Direito Internacional tiveram de ser procuradas nos livros indianos que, de acordo com os títulos, parecem se referir mais à Religião do que ao Direito.

Do rico acervo indiano extraem-se passagens da doutrina jurídica, encontradas na décima segunda parte - o Santi Parva - e tem como suposto Autor um sábio chamado Bishan, que narra deveres do Rei e deveres especiais em tempos de dificuldade; e as Leis de Manu, escritas em 300 d.C., contendo instruções sobre deveres morais e sociais, tais como a conduta das diferentes classes sociais. Manu é considerado o primeiro homem com o perfil de "excelente legislador".

\section{Cristianismo. Direito Canônico}

O Cristianismo é a Religião dos seguidores de Jesus Cristo que acreditam ser Ele o Filho de Deus e o Messias, cuja vinda de retorno à Terra fora prometida no Velho Testamento da Bíblia.

Cerca de 300 anos depois da morte de Jesus, o Cristianismo Apostólico se tornou a Religião oficial do Império romano, sob o comando do imperador Constantino que se converteu e fora batizado antes de sua morte; a Fé se expandiu da Palestina para a Europa, o Oeste da Ásia e o Norte da África e, por meio da pregação e ensinamento constantes, continuou a se espalhar por todo o Mundo. Desde o século XVI, colonos europeus trouxeram a Fé cristã para as Américas, e no século XIX houve grande expansão, quando missionários seguiram os colonizadores europeus em várias regiões da África e da Ásia. Atualmente há mais de 3 bilhões de cristãos em toda parte do Mundo; pertencem, sobretudo, a três grandes grupos: católicos, ortodoxos e protestantes, os quais divergem quanto à doutrina e rituais; todavia, compartilham crenças básicas cristãs. 
Dentre os primeiros seguidores dos ensinamentos cristãos, os esforços do missionário Saulo, falecido em 65 d.C., incentivador do avanço da Religião cristã e auxiliando em sua consolidação segura no auge do Império romano. A conversão de Saulo aconteceu durante a sua jornada na Estrada de Damasco, após a visão de Jesus, que mudou o seu nome para Paulo; homem centurião que falava vários idiomas, porte elegante e belo e empreendedor de série de projetos missionários ao redor do Mediterrâneo, além de fundador de várias Igrejas na Ásia Menor, Síria, Chipre e Grécia. Paulo era escritor e dentre seus trabalhos redigidos, a famosa Coleção de Epístolas ou Cartas que integram o Novo Testamento.

A outro discípulo, Simão, Jesus passou a chamá-lo de Pedro, significado de "pedra" ou "rocha", fundamentando que o pescador - sua profissão - deveria ser a base da Igreja primeva. Após a ascensão de Jesus, Pedro se torna o líder dos cristãos. Ele pregou em partes do Mediterrâneo e funda a Igreja cristã em Roma. Tudo o que se sabe sobre Jesus - que nada deixou escrito - está contido nos quatro primeiros Livros do Novo Testamento da Bíblia: os Evangelhos de Mateus, Marcos, Lucas e João; quatro discípulos de Cristo que narram os anos de sua pregação na Galileia como, também, a descrição de sua morte e ressurreição, a parte mais significativa de todos os relatos, uma vez cristãos acreditarem que ao sacrificar o Seu Filho, Deus lhes trouxe a salvação e a oportunidade de uma nova vida eterna.

No avanço do Cristianismo, desde os tempos da Igreja primitiva havia entre os primeiros cristãos um grupo que tinha o hábito de realizar coleção de sagrados cânones, no intuito de facilitar o conhecimento religioso junto ao Direito Consuetudinário e Direito Natural - hábito aliás herdado dos sacerdotes judeus -, principalmente a observância na conduta que deveriam seguir os ministros sagrados, em recinto religioso. Em 633, o IV Concílio de Toledo prescrevia que os sacerdotes deveriam conhecer as Escrituras Sagradas e os cânones; época de novos caminhos na restauração da Igreja, encontrada em pleno caos. O iniciador desse cômputo religioso é atribuído ao Papa Celestino e no decorrer dos doze primeiros séculos floresce em vários lugares série de coletâneas de Leis eclesiásticas, a maioria compilada por cristãos e em caráter particular, cujo conteúdo apresentava nomes emanados dos Concílios e dos Romanos Pontífices. Neste acervo do século XII, composto ou reunido por um monge chamado Graciano, que havia tido a ideia de se estabelecer a concordância das Leis como, também, das anteriores coleções. $\mathrm{O}$ monge os colocou em ordem de importância junto às criteriosas regras de temas e assuntos pertinentes ao Cristianismo católico. O conjunto deste trabalho veio a se intitular Decretum Gratiani que, de fato, constitui a primeira parte da Coletânea de Leis da Igreja moderna - em parâmetro ao Corpus Juris Civilis, do imperador Justiniano -, chamado de Corpus Juris Canonici. 
Em período de dois séculos, o Corpus Juris Canonici, contendo as Leis elaboradas pela Suprema Autoridade dos Romanos Pontífices fora auxiliado pelo Decreto de Graciano - documento da coletânea das Leis anteriores minuciosamente reunidas - e constante no Liber Extra, de Gregório IX, do Liber VI, de Bonifácio VIII, das Clementinas (coleção de Clemente V) e promulgados pelo Papa João XXII, além das Extravagantes, deste Pontífice, e das Extravagantes Communes, decretos de vários Romanos Pontífices e nunca reunidos em autêntica coleção. O Corpus, da Igreja latina possui similaridade ao Syntagma Canonum, da Igreja grega.

As Leis posteriores ao período da Reforma católica estipuladas pelo Concílio de Trento - mais tarde promulgadas por vários Dicastérios, da Cúria romana -, nunca foram reunidas em coletânea. No Concílio do Vaticano I, bispos solicitaram para que se fizesse nova e única coletânea de Leis, no intuito de se poder oferecer maior certeza e segurança à Cúria Pastoral do Povo de Deus, tarefa iniciada mais tarde pelo papa Pio X e sucedida pelo Papa Bento XV, que a finalizou, depois de vinte anos, em 27 de maio de 1917 e vigência em 19 de maio de 1918. Nova revisão, solicitada pelo Papa João XXIII, fora realizada pelo Concílio do Vaticano; o novo Código Canônico é publicado em 25 de janeiro de 1983, declarado vigente pelo Papa João Paulo II.

O Código de Direito Canônico é um "conjunto de normas de origem divina e humana; normas reconhecidas e promulgadas pela Autoridade da Igreja cristã católica, que determina organização e atuação da própria Igreja e seus fiéis em relação aos fins de que lhes são próprios", definição, aliás de autoria do professor Rafael Lhano Cifuentes, de Salamanca, Espanha. A maioria da Legislação europeia - como a da Itália -, tem institutos jurídicos regulamentadas pelo Direito Canônico, por meio do sistema de remissão ou reenvio. Na América latina católica, Estados como Brasil, Chile e Uruguai reconhecem valor jurídico a determinados atos como o do consentimento matrimonial, realizado tanto em cartórios de registro quanto em solenidades religiosas, enfatizando Igreja e fiéis católicos.

Na Idade Média se entendia que o povo deveria se submeter aos preceitos da Lei divina, estabelecidos nas revelações realizadas pelo Deus Único; dentre eles, o da Igreja, depositária e aos preceitos da Lei Positiva que o próprio homem formulava, adaptando os princípios da Lex Naturalis à sua comunidade. Por quê? Porque o Direito era constituído por normas consuetudinárias emanadas pelo mais forte, tanto que a palavra iustitia se alastrou, a ponto de se designar "o conjunto dos poderosos senhorios diretamente tutelados pela Igreja cristã católica, composta por um corpo de clérigos - senhores de espada e poderes temporais -; Reis e imperadores não eram chefes de Estado, mas na função de príncipe que lhes prestavam a hominium ou homagium; todavia, acobertados de direitos soberanos e seu próprio senhorio territorial”. Esta lição é procedente e apreendida com o filósofo, historiador e economista Karl Kautsky, de Praga, República 
Tcheca. Assim como o Direito Romano, o Direito Canônico influenciou e ainda influencia ordenamentos jurídicos em quase todos os Estados católicos, enfatizando europeus e latino-americanos.

\section{Cristianismo ortodoxo. Direito russo}

A Igreja ortodoxa se torna a principal Religião da Rússia e do Leste e Sudeste europeus; atualmente com mais de 550 milhões de adeptos e diverge em atos da católica. Paralela à Russkaia pravda - o Direito laico da Rússia -, existe outro Direito: o Direito Canônico, totalmente diferente daquele conhecido no Ocidente, o Direito Canônico de Bizâncio, composto por série de nomocanons, embasado no nomocanon do patriarca Photius, do ano de 883. Esses nomocanons contêm concomitantemente o Direito Civil (nomos) com o Direito Canônico, no intuito de os clérigos poderem conhecer toda a Coletânea - associada às disposições editadas -, das quais estarem submetidos. Além disso, tinham o dever de aplicá-las, tanto que a Igreja russa transita juridicamente conforme os dispositivos do Direito Canônico.

Enfim, o Direito bizantino veio a desempenhar importância jurídica no Estado russo e o mentor da reforma da Igreja ortodoxa tem como Autor Martinho Lutero, de nacionalidade alemã, que reprovava veementemente a prática da Igreja católica, por meio da venda de indulgências promissoras o perdão de Deus aos homens pecadores. Lutero redigiu mais de 25 teses/argumentos na intenção de protestar essas práticas, afixando parte desses documentos nas portas da Igreja de Wittenberg, além de traduzir as Escrituras para o idioma alemão, na certeza de que mais cidadãos comuns pudessem entendê-las, dando margem ao Movimento Reformista, que se espalha por toda a Europa até as Regiões onde o Paganismo estava se extinguindo, como a da antiga Escandinávia pagã, na cidade de Uppsala, mais tarde adepta do Cristianismo ortodoxo.

Advindo o Cisma, à Igreja ocidental - sediada em Roma e a oriental em Constantinopla -, a divergência atingia a essência da Fé e, em 1054, total ruptura se torna cristalina, conhecida na História da Religião como o Grande Cisma ou Separação: nasce definitivamente a Igreja ortodoxa, que nada mais é do que uma corrente do Cristianismo eclesiástico. A ortodoxia é robusta na Grécia, Turquia, em Chipre e no Leste europeu, enfatizando as belas Rússia e Bulgária, lembrando, por último, que a ortodoxia cristã é intitulada Cristianismo oriental. O Islamismo se faz presente na Rússia; porém, em pequeno cômputo. Mas do lado europeu russo, o aspecto fiel do Paganismo continuou em persistência até o século XI, o que se comprova no seio da Família real, uma vez o Príncipe Vladimir ter desposado cinco esposas, além de concubinas, época em que missionários búlgaros entram em Regiões remotas russas no intento de trabalhos religiosos ortodoxocristãos a serem realizados. Em seguida, a Igreja presbiteriana e seus mentores - Lutero 
e do francês Calvino - que atinge, atualmente, a jornada de 500 anos e fiéis em todo o Mundo.

A separação Igreja, da Escola da Igreja, a liberdade de consciência foram consagradas, legislativamente e pela primeira vez, na Constituição soviética, de 1918, complementada na Constituição de 1936 e na de 1977. Na tese de Lênin:

... o Estado não deve ter nada a ver com o a Religião, as uniões religiosas não devem também estar vinculadas ao Poder do Estado e cada indivíduo, por sua vez, deve ter plena liberdade de professar a Religião que queira ou de não-reconhecer nenhuma.

A quinta Constituição, de 1993, é consagrada após a Rússia ser desmembrada e internacionalmente elogiada, promulgada em 1994 é respaldada em modelo constitucional francês, tendo à frente a posição de um Presidente forte ... e na Declaração Universal dos Direitos Humanos. Dentre os avanços, o Código Penal - embora considerado um pouco fraco pelos legisladores internacionais - desde a sua origem, em primeiro de janeiro de 1977; todavia, fantástica evolução à recomposição do Direito russo.

A pesquisadora Ekaterina Lagoda, do Departamento de Direito Estatal e Internacional da Universidade de KubGAU, Krasmodar, Rússia, assevera que:

a Federação russa passou por diversas etapas na formação da liberdade, de consciência e de Religião inseridos na Constituição vigente de 1993. Os princípios da liberdade e de consciência e a não-discriminação em relação à Religião criaram as condições necessárias para a existência de um país multiétnico e multirreligioso. No entanto, a realização prática do complexo destes direitos e liberdade provoca uma série de complexidades e contradições. As características atuais da Legislação russa no âmbito da liberdade de consciência e de Religião têm a hierarquia e formação das fontes: nos princípios e normas do Direito Internacional; na Constituição de 1993; na Lei federal de 1997, intitulada 'Da liberdade de consciência e associações religiosas'; nos códigos da Federação russa: civil, administrativo, tributário e trabalhista; nos atos federais de nível secundário; nas outras normas federais que tratam das questões de liberdade de consciência, liberdade de Religião e de atividades das associações religiosas; e nos atos normativos legais do Sujeito da Federação.

O Comunismo russo perdeu força nos anos 1980, quando o Papa João Paulo II consagrou a Rússia, tocando sensivelmente Mikhail Sergeevitch Gorbatchev e o país - que apregoava o ateísmo - se transforma modificado mais para o lado religioso. Atualmente, o Capitalismo se faz vigente, coordenado por chefe forte do Governo russo: Vladimir Putin, respeitado e aclamado tanto pela geração antiga quanto pela nova-que 
nem conheceu outro chefe de Governo -, gloriosamente segue em seu quarto mandato (término em 2024), resultado de dezoito anos na Presidência - sem se computar os anos no cargo de primeiro-ministro -, reeleito com mais de 76\% dos votos, neste ano de 2018. A anexação da Crimeia - que pertencia à Ucrânia - à Federação russa, em sua administração, logrou absoluta confiança de seu povo, embora haja críticas internacionais quanto ao seu relacionamento influenciador, apontando-se Geórgia, Chechênia, Síria e eleição presidencial norte-americana, além da espionagem internacional como o ocorrido na Inglaterra, esta considerada pelo presidente russo "ridicula".

6. Budismo. Taoismo. Confucionismo. Direito chinês

Em avaliação do regime religioso-jurídico, se conclui que a maioria dos chineses é taoista em casa, confucionista fora dela e budista na hora da morte; afirmativa de pesquisadores e historiadores que, por sua vez, resume a complexa espiritualidade desenhada pelo povo ancestral chinês e cidadãos contemporâneos desta Nação, uma das mais antigas da História da Humanidade com mais de seis mil anos a serem narrados. A China contempla Livros Raros das três doutrinas, em cômputo de mais de vinte séculos e é por isso o interesse de estudiosos para compreender a gigante Nação, nos dias atuais; o que se realiza recorrendo ao passado, por meio de Confúcio, Tao e Buda, o trio que explica os usos e costumes dessa civilização e sua relação com o Mundo, uma vez a Religião Popular chinesa ser vista como importante parte do seu universo.

A Religião Tradicional costuma ser confundida com o Taoismo, porque durante séculos o institucional tenta administrar as Religiões locais, lembrando que a designação "religiões tradicionais" é empregada na definição do vasto conjunto de sincretismos, crenças práticas e valoração nas diferentes Religiões orientais e forte impacto de expressão. Esse conjunto - qualificado de "crenças populares" ou "crenças tradicionais" - foi adaptado e desenvolvido ao longo de aproximadamente seis séculos, revelando o caráter altamente sincrético e prático. Todavia, do lado espiritual, conseguiu criar uma unidade compatível mediante tanta diversidade entre diferentes Religiões. E também, neste conjunto, se encontra a valoração do Taoismo, do Budismo, da Mitologia chinesa, além demais usos e costumes, tais como crença, superstição e práticas tradicionais, sendo o culto aos antepassados considerado fundamental e mola-mestra para a formulação do Sistema Jurídico chinês.

A cultura chinesa não é orientada pelo Direito: segue evolução própria, porque o Sistema Jurídico tradicional fora totalmente integrado em concepção filosófica e, nessa pauta, se enfatiza o Confucionismo, influenciado pelos pensamentos jurídicos tanto do lado confucionista quanto do legalismo. 
Aos Livros apontados, na verdade são textos - embora chamados "Livros" -, no âmbito do raciocínio e pensamento confucionista. São eles: os "Analectas", "Mêncio", o "Grande Aprendizado" e "Doutrina do Significado". Zhu Xi, filósofo do século XII, escreveu série de comentários sobre os Quatro Livros e sua obra inspirou um confucionismo, favorecendo tanto o aprendizado quanto a moralidade; dentre eles, o do termo "Li" que possui dois significados, em consonância com a Teoria de Confúcio: representa a correta conduta pessoal ou, ainda, o ritual adequado a ser cumprido em determinadas cerimônias. Zhu Xi observava o sentido mais profundo no "Li": dizia que representava a força e a essência suprema que fundamenta a existência da vida. Seus Livros se tornaram a base da Educação chinesa.

O Comunismo chinês vitimou o Taoismo Religioso, por meio de perseguição; porém, as tradições foram mantidas, ressurgindo, gradativamente, e influenciando o Confucionismo - antigo e moderno - na construção jurídica do Direito chinês que, por sua vez, não utilizava Leis escritas que pudesse tornar teorias gerais, mas valorizava usos e costumes, ou seja, a preservação dos bons hábitos. E desta maneira as normas escritas que possuíam forte atuação e a ideia de conciliação - tinham a premissa maior. Enfim, o Direito escrito se posicionava sempre em segundo plano.

Por fim, o Direito chinês era visto na sociedade como forma de punição e por isso se usava a expressão " $F a$ " (punição), substituindo a Lipreservação, a melhoria, base de Governo justo; o " $L i$ ”, era utilizado em parâmetro às regras de conduta, expressão de ideograma clássico de utilidade mais filosófica. Atualmente, os magistrados chineses são indicados pelos membros dos órgãos administrativos do Congresso Nacional Popular - cuja Constituinte atual é aprovada a manter o líder presidencial em caráter permanente no cargo -, controlado há muito tempo pelo Partido Comunista chinês, o que tem causado instabilidade, pois são substituídos em qualquer ocasião, demonstrando falta de solidez ao Poder Judiciário chinês. Atualmente, o Governo chinês é presidido por Xi Jinping, moderado e disponível aos diálogos de pautas contendo temas de nível internacional.

\section{Islamismo. Châr'ia muçulmana}

Os seguidores do Islamismo são chamados muçulmanos. A palavra islã significa submissão: a Religião envolve incondicional submissão à vontade de Deus, conhecido por eles como Alá e acreditam que sua Fé foi revelada por Deus ao profeta Mohammad (Maomé) que viveu na Arábia entre 570 a 632 d.C., cujas palavras foram coligidas mais tarde no Livro Sagrado do Islamismo, o Qur'an (Corão ou Alcorão). Assim que a Fé fora revelada a Mohammad, o Islamismo se difundiu rapidamente pelo Oriente Médio e pelo Norte da África, lembrando que o Oriente Médio ainda é o centro do mundo islâmico e essa Fé predomina em todos os países da Região, exceto Israel. 
Os muçulmanos se voltam para a Meca ao rezar e esperam visitá-la em peregrinação ao menos uma vez na vida, conforme visto acima. Também existem muçulmanos em países do Leste da Ásia, como a Indonésia.

A obra intitulada Introdução Histórica ao Direito apresenta definição do Direito, segundo o Qu'ran, de autoria de John Gilissen: "a Châr'ia muçulmana é o 'Direito' da comunidade religiosa islâmica, ou seja, o Direito que rege todos os adeptos da Religião islâmica, onde quer que eles se encontrem”.

René David nos ensina que a Châr'ia muçulmana é totalmente independente de outras espécies de mando (nómos), enquanto as "semelhanças que podem apresentar neste ou naquele ponto em soluções com outros sistemas só podem ser atribuídos, segundo a ortodoxia muçulmana, a simples coincidência; em alguns casos podem tratar-se de empréstimos" que a Châr'ia muçulmana “teria feito a um pensamento estrangeiro". Por outra, sua influência sobre as espécies do mando europeias é quase nula.

Um dos expoentes da História do Oriente, professor Hugo Hortêncio de Aguiar, ex-coronel do Exército apresenta clássica definição em sua obra intitulada Islamismo e Estado sobre a Châr'ia e a Religião islâmica:

Nos países árabes, a imortalidade da alma é um preceito legal e o Direito deve proporcionar os meios para que o seguidor atinja em boas condições essa imortalidade. Por outro lado, o Direito deve proporcionar os meios para o bem-estar dos muçulmanos, bem como regular as punições para os limites da liberdade individual. Como o Direito e paralelamente a Moral são emanados com prevalência do Divino, é quase juridicamente impossível se saber onde termina o Direito e começa a Moral, e vice-versa.

Mediante as inúmeras e significativas divergências de interpretação do Qu'ran, chega-se à conclusão de que a Châr'ia muçulmana, segundo a teoria islâmica, depende mais da consciência do individuo do que do Poder Estatal que, dessa maneira, assume contornos político-administrativos especiais: cristalina influência da Religião sobre o Direito!

\section{A nova Religião/Filosofia: a Espírita}

Adepta à Lei da Evolução, a Religião Espírita é a recente parceira da doutrina jurídica internacional, ao asseverar que os homens têm direito na busca do seu bem-estar, mesmo porque não é crime a busca deste estado social, ao se definir que criminosa é a ignorância em que vêm sendo mantidos acerca de seus direitos naturais, direitos inerentes à sua condição de filhos de Deus sem acepção de raça, cor ou nacionalidade. 
Criminosas são as manobras do egoísmo empregadas por minoria dominante, no sentido de impedir o advento da Justiça social e consequente melhoria do padrão de vida da civilização em geral. Criminosos são os gastos exorbitantes que se fazem por toda a parte em programas armamentistas, em detrimento da produção de bens de consumo ao desvio de vultosas parcelas da Humanidade, exatamente os elementos mais válidos, dos trabalhos fecundos que ativam a civilização para a improdutividade das casernas - quartéis militares - ou, o que é pior, para as operações bélicas que destroem em minutos o que levou séculos para se edificar.

Essas lições são de autoria do professor José Fleurí Queiroz.

Nesse influxo, a Doutrina Espírita mediante a Lei de Evolução pela qual tudo se engrandece e prospera, os mundos também progridem, pois se destinam a oferecer aos seus habitantes, condições de morada cada vez mais aprazíveis. ["Há muitas moradas na Casa do Meu Pai”, disse Jesus de Nazaré]. Premissa final: não é possível de que a Terra permaneça eternamente como Mundo de expiações e de provas. Para os Espíritas, existem muitos outros mundos, sendo o próximo o de regeneração e, o último, o Mundo celestial, morada do Deus Único.

A mola-mestra de ensinamento da Religião Espírita é o Cristianismo que relata o aperfeiçoamento da estrutura socioeconômica das Nações terrenas, além de imperativo categórico; e bom seria que, ao invés de resistir às medidas que favoreçam as classes privilegiadas - em cujas mãos se encontram as rédeas do Poder -, renunciassem espontaneamente a algo do que lhes sobeja em favor do bem-estar coletivo. Isso evitaria os processos violentos e dolorosos que vêm sucedendo ao longo dos tempos modernos, a exemplo da recente classe humana, os refugiados, em busca de trabalho e alimento, expulsos por questões religiosas de suas casas e terras até a Marcha do Progresso, neste minúsculo planeta, inaugurando nova Era, de compreensão e boa vontade, que os reacionários batizarão com outros nomes, mas que representará o triunfo do Cristianismo, em sua expressão mais autêntica, mais nobre e mais bela. O bem-estar é desejo natural!

Codificação, do francês codification, é a ação de codificar, de reunir em um código textos de Leis e Regulamentos; ação de reunir Leis em códigos, de trasladar um texto em código, de criar ou organizar um código, um sistema. Codificador é aquele que codifica, que reduz o código, segundo Aurélio Buarque de Holanda ("Dicionário da Língua Portuguesa"). Allan Kardec (1804-1869) é o codificador do Espiritismo em sua doutrina, reuniu em forma de código, de maneira sistemática, cinco Livros fundamentais, o conjunto das Leis Divinas reveladas pelos Espíritos Superiores. O primeiro - que representa os fundamentos da Filosofia Espírita - intitula-se O Livro dos Espíritos, editado em 18 de abril de 1857 . Ele fundou em Paris a $1^{\circ}$ de abril de 1858 a primeira Sociedade Espírita regularmente constituída sob o nome Sociedade Parisiense de Estudos Espíritas, 
cujo fim exclusivo era o estudo de tudo o que possa contribuir para o progresso desta nova Ciência.

Dos Livros inseridos, o III ("Das Leis Morais”) e V ("Esperanças e Consolações”), o professor, advogado, músico e escritor José Fleurí Queiroz publica, de sua autoria, o Código de Direito Natural Espírita ou "Código Fleurí", comentado e desenvolvido por seus pares escritores, rigorosamente à luz da mais completa pureza doutrinária kardecista; uma coletânea extraordinária que aborda as áreas jurídicoreligiosas.

Em 2012, o promotor de Justiça, pós-graduado (doutor) pela Faculdade de Direito da Universidade de São Paulo e líder do Movimento Jurídico-espírita paulista, Tiago Cintra Essado, coordena, junto a seus pares - magistrados e filósofos -, a obra Direitos Constitucionais e Espiritismo, lembrando que o Direito Administrativo, apêndice do Direito do Estado, afina-se com os preceitos fundamentais da Doutrina Espírita em seu artigo intitulado Princípios da administração pública à luz do Espiritismo, destacando a importância da moralidade e da supremacia do interessa público na busca do Justo, em parâmetro maior do que a da simples aplicação da Lei. Uma mostra valiosa da parceria espiritismo-jurídico em cômputo de dezesseis artigos doutrinários, cujos autores têm como foco o tema assinalado.

O homem que virou ícone de divulgação do Espiritismo do Brasil para o Mundo foi o mineiro Francisco (Chico) Cândido Xavier, que destacava os preceitos cristãos, dando exemplos, por meio de sua própria vivência, e mostrando que a Doutrina que pregava - a existência da vida após a desencarnação do corpo físico e, posteriormente, a reencarnação - era, em primeiro lugar, uma Religião estritamente cristã. A figura divina de Jesus Cristo estava presente na vida do saudoso médium e ele fazia questão de pregar o Espiritismo Evangélico, ensinando que o homem deve seguir os exemplos de Cristo para amenizar as suas dores. Ele escreveu mais de 420 títulos psicografados e teve milhões de exemplares vendidos e traduzidos em vários idiomas; dentre eles, francês, inglês, japonês, grego e esperanto. O seu primeiro Livro intitula-se Parnaso de Além-Túmulo, de 1932, que trazia poesias de grandes autores da Literatura mundial.

Por fim, cumpre salientar, que a sua vida apostolar foi dedicada aos necessitados e sofredores provindos de longínquos lugares como, também, os afazeres medianeiros que ocupavam seu tempo disponível; e por eles não aceitava, em absoluto, qualquer espécie de pagamento, incluso os direitos autorais, cedia graciosamente a várias Editoras e Casas Espíritas, desde o primeiro Livro lançado.

O ordenamento jurídico brasileiro, Direito Positivo, tem evoluído por meio dos tempos; todavia, encontra-se distante dos princípios da verdadeira Justiça. O Direito da Força ainda prevalece sobre a Força do Direito; o orgulho e o egoísmo são forças terríveis que orientam os legisladores, cegando-os e impedindo-os de verem a Verdade. 
Sendo assim, a Justiça do Direito Positivo não se identifica com a Justiça do Direito Natural Espírita: enquanto a primeira busca seus postulados na Ciência da Matéria, a segunda apoia seus princípios na Ciência do Espírito, Ciência esta que só é possível atingir com o aperfeiçoamento da Humanidade que, por sua vez, só será alcançado com o conhecimento das Leis Naturais, de ordem moral, reveladas pelo Espiritismo e codificadas, cientificamente, por Allan Kardec, mediante observação dos fatos paranormais e das consequências filosóficas e morais dos mesmos.

O conhecimento é o maior patrimônio do ser humano como assevera Sócrates "quem conhece não erra" ou a de Jesus de Nazaré "conheça a Verdade e ela vos fará livres"; mas o conhecimento real só se obtém com o estudo integrado do triângulo Ciência, Filosofia e Religião, uma vez áreas de origem única: a Lei Natural Divina, traduzida por Deus, o Supremo Legislador. Das Federações Espíritas brasileiras, a mais antiga é a União Espírita Paraense, de 1916.

\section{Conclusão}

Nas intermináveis pesquisas sobre nossos ancestrais - pioneiros a habitar o planeta presume-se que sem eles, gênios do passado, não conheceríamos boa parte do nosso Mundo; como, por exemplo, atravessar oceanos... seria um sonho -, chega-se a uma conclusão diferenciada: por alguma razão, sempre foram animais religiosos em parâmetro aos outros da mesma espécie; filósofos materialistas do século XIX tentaram justificar essa virtude, por meio da superstição, uma vez homens primitivos não-compreender como o raio e o trovão, elementos da Natureza, se manifestavam, decidindo que os elementos eram deuses vivos na tentativa de se conectar.

Historiadores, cientistas, jornalistas e pesquisadores examinadores minuciosos das Religiões e sistemas de crenças englobados neste Mundo, logo reconhecem que isso não é tudo. Pois bem, a maioria dos animais se encontra satisfeita e confortável desde os inteligentes Neandertais (Homo sapiens neanderthalensis) ${ }^{11}$-, quando encontra alimento, água, clima ameno e abrigo, sendo, também, os únicos movidos por enigmática

\footnotetext{
11 Por milhares de anos, uma espécie humana primitiva habitou a Europa e o Oriente Médio: seu nome, homem de Neandertal, provém do Vale próximo a Düsseldorf, na Alemanha, onde suas ferramentas foram encontradas, pela primeira vez, em 1856. Atualmente o que se registra é a de que essa espécie perdeu a luta pela sobrevivência há mais de 30/35 mil anos atrás, quando todos os rastros dos Neandertais desapareceram. E nessa época, outra espécie chamada "homo sapiens sapiens" começou a se propagar pela Europa, provavelmente a partir do Oriente Médio e os indícios mais antigos do homem, anatomicamente moderno, foram encontrados em 1868, nas margens rochosas do Rio Vézère, Região Central da França, em uma caverna que abrigava a sepultura de três homens, uma mulher e uma criança. Esse tipo primitivo foi batizado "Cro-Magnon", nome do local onde foi descoberto.
} 
necessidade de transformar a si próprios, notando-se que demasiada felicidade costumava entediá-los.

O homem tem toda a premência de compulsão biológica - a exemplo da lagarta que precisa se transformar em crisálida antes da metamorfose final, em borboleta - e mesmo os ancestrais têm perfil de adoração à Natureza, ligando-a à realidade espiritual superior que, mais tarde, se denominaria Deus, o Pai Todo-Poderoso, Eterno, Criador de todas as coisas ou o Divino.

Cientificamente, é comprovado que nossos ancestrais habitam o minúsculo planeta Terra há, pelo menos, quatro ou cinco milhões de anos, idade estimada pelos ossos encontrados do esqueleto batizado pelos pesquisadores - da equipe de escavação de "Lucy" na Bacia de Afar, ao Norte da Etiópia, África, em 1974, cuja idade estimada abrange cerca de três milhões de anos.

A Bacia de Afar é uma das Regiões mais inóspitas do Mundo, assim como outras igualmente situadas em terras africanas e tem fornecido aos cientistas valioso material, tornando, assim, possível escrever uma das primeiras páginas da pré-história da Humanidade. Outros indivíduos da mesma espécie - Australopithecus afarensis foram descobertos, desde então; simultaneamente, vestígios encontrados em outros sítios de escavação africanos trouxeram novas contribuições para o conhecimento desses ancestrais dos seres humanos modernos. Nesses sítios, foram desencavados alguns dos achados mais valiosos, como o Ardipithecus afarensis, com cerca de 4,4 milhões de anos e os mais antigos exemplares dos hominídeos modernos, ancestrais mais próximos dos humanos atuais.

Premissa final: atualmente é consenso, entre os paleontólogos, de que a África seja o berço da Humanidade; todavia, a ausência de vestígios de hominídeos remotos fora da África continua a intrigar a Ciência. A busca pelo conhecimento é a força que move o Mundo.

Em 1929, em caverna localizada perto de Pequim, Zhoukoudian, paleontólogos encontraram ossos de remoto ancestral do homem moderno, batizado de "Homem de Pequim", sabedor do uso do fogo e aprendiz na degustação da carne da caça, assando-a. Mas também encontraram quarenta crânios humanos abertos para se tirar o cérebro. Os canibais existentes na época moderna creem que devorar o cérebro do inimigo permite ao guerreiro vencedor se apoderar da força e da inteligência do perdedor. Conclusão: se o "Homem de Pequim" se entregou ao canibalismo ritualístico, é porque já tinha alguma formação religiosa e é impossível imaginar um ritual religioso destituído de alguma forma de comunicação verbal. Enfim, usos e costumes que favorecem a explosão do cérebro para o desenvolvimento da linguagem e esta comunicação verbal é extremamente vinculada ao sentido religioso humano, lembrando que há 100 mil anos, os homens Neandertais usavam flores e ramos silvestres nos rituais religiosos de 
inumação de seus mortos como, também, esculpiam pedras chatas e circulares, o que sugere a adoração do Sol. Inacreditavelmente, embora semelhantes aos macacos bonobos, ancestrais acreditavam na vida após a morte e essa crença não deixa de ser o denominador comum entre todas as Religiões.

No século XIX, o filósofo Augusto Comte sugeriu que "a Religião é uma tentativa pré-científica para se entender o Universo" e isto revela incapacidade para se entender algo básico sobre a relação do homem com a Natureza. Exemplo, sábios chineses quando descreviam montanhas como "lugar sagrado”; não estavam projetando superstições sobre elas, estavam cientes de que as montanhas são um ser vivo que contêm em siforça telúrica. Por quê? Porque esses sábios orientais chineses acreditavam que linhas de força sagrada. "feng shui", correm através dos campos montanhosos, transmitindo energia universal.

Antigos "lugares sagrados" continuam a ser, lembrando que nas primeiras Religiões Primevas da Humanidade se adorava a Natureza, enfatizando as montanhas e quando do início das edificações religiosas - as pirâmides de Gizé ou as do México -, elas tinham o formato de montanhas. A Religião Primeva inspirou obras impressionantes de Arte e Arquitetura como, também, inspiração poderosa aos esforços humanos (Stonehenge, Angkor Wat, do Império kmer, Borogudur, Machu Picchu, Ilha de Páscoa, Luxor, Jerusalém).

Sem as montanhas, o nosso planeta não teria sobrevivido; elas são um baú de riqueza mineral (carvão - dando origem à indústria -, cobre, estanho, prata, ouro, uma vez escavadeira natural e protetora da explosão de encontros oceânicos, ensinada pela Geologia, quanto aos deslocamentos das placas tectônicas), guiam os passos dos homens, nos dividem em várias civilizações. Devido às alturas e gravidade planetária são fontes de águas em queda, auxiliadas pelos ventos naturais, trazendo abundância de chuvas. Elas são milagrosas!

Na Região da Anatólia, Turquia, se encontra o sítio do mais antigo templo da História da Humanidade e da Religião Primeva: Göbekli Tepe; trata-se de imensa área esculpida em complexas cavernas em cujo interior ancestrais arquitetos construíram diversos blocos de pedra em formato de um “ $T$ ”, cujo significado até hoje é enigmático, incluso a origem de sua civilização. Nela, a presença da Religião registrada em pedras; como exemplo, a estátua exposta de museusk turco: um ser - sem a cabeça que fora destruída - segurando um recém-nascido e aos seus pés, duas serpentes, símbolo da fertilidade. As mãos do ser esculpido - que não parece nada humano - estão envoltas até o umbigo, demonstrando carinho amoroso ao nascido; a data prevista é a de 10 mil anos a.C.

O antropomorfismo das Religiões reveladas, Judaísmo e seus dois prolongamentos, Cristianismo e Islamismo, comprovam que a Ética e o Direito derivam da Religião, por se tratar de necessidade inafastável das sociedades antigas, no Período 
Neolítico, regrar a vida dos agrupamentos humanos a se formar mais tarde. E as normas de conduta, éticas ou legais, eram decretadas por deuses e executadas por sacerdotes, porque terminam sempre por julgar as condutas das pessoas encontradas sob o domínio de normas jurídicas editadas por Deus ... ou deuses. Esse conjunto é classificado por Sacha Calmon de Antropomorfismo Cultural em A história da mitologia judaico-cristã.

Somente no século XVIII o Direito aportou-se da Ética e da Religião, separação que se acentuou nos séculos XIX e XX, resultando consequências importantes; e em uma delas a de qualificar o Direito como regras do homem e a Religião como Leis de Deus. O saldo, o de a Religião perder normatividade legal, compensada por acréscimo de metafísica transcendental; porém, as normas organizatórias e comportamentais continuam a jorrar da Ética e da Religião e do Direito e é como vemos o fenômeno da normatividade jurídica, neste século XXI. Lembra-se que no passado a Lei humana dimanava diretamente dos deuses e é precisamente por isso que as Religiões reveladas terminam suas respectivas teodiceias em monumentais julgamentos dos seres humanos; exatamente como ocorre entre os sistemas jurídicos legislados pelos homens. Neste painel, o Direito Natural, aplicado pela maioria das coletividades religiosas.

O emérito professor Goffredo da Silva Telles Júnior, orgulho pessoal de ter sido seu aluno, criador do termo Direito Quântico na intenção deliberada de assinalar que as Leis - criações da inteligência para a ordenação do comportamento humano em sociedade -, são tempestivas expressões culturais de subjacentes silenciosas e perenes disposições genéticas da Mãe Natureza. O filósofo nos ensina que

um Direito autenticamente natural é sempre um conjunto de normas jurídicas, ou seja, um conjunto de normas autorizantes e toda norma jurídica é norma declarada pela inteligência governante; norma promulgada por quem tem competência para promulgá-la. Embora nem todo Direito promulgado é Direito Natural que só o é Direito promulgado consoante com o sistema ético de referência da coletividade em que ele vigora. E todos os Direitos promulgados consoantes com os seus respectivos sistemas éticos de referência são Direitos Naturais. Existem tantos Direitos Naturais quantos são as coletividades dotadas de ordens jurídicas, consoantes com seus respectivos sistemas éticos de referência.

Em suma, segundo Telles Júnior,

o Direito Natural é o conjunto das normas autorizantes em que a inteligência governante da coletividade consigna os movimentos humanos que podem ser oficialmente exigidos, e os que são oficialmente proibidos, de acordo com o sistema ético vigente. 
Premissa final: o Direito Natural é o Direito legítimo.

Tanto a Lei de Deus quanto a Lei do homem exigem cumprimento, sob pena de aplicação de sanções e uma distinção, com certeza, há de ser feita: a Lei e a Jurisprudência dos sistemas de normas dos homens evoluem com o tempo e as circunstâncias; já a Lei Divina não pode mudar, é imutável, uma vez o seu legislador ser o Deus Único, mas pode ser "interpretada", segundo as circunstâncias políticas e temporais dos milênios. Enfim: o Direito hoje prescinde das Religiões, que trabalham para obter comportamentos desejáveis e coibir os indesejáveis como o sistema de recompensa post mortem.

São Paulo, fevereiro de 2018.

\section{Referências}

AGUIAR, Hugo Hortêncio de. Islamismo e Estado. Revista de Informação Legislativa, Brasília, v. 38 , n. 152 , p. 269-274, out./dez. 2001.

BALTHAZAR, Jean (Red.). Os últimos mistérios do mundo. Tradutor Braulio Tavares. Rio de Janeiro: Reader's Digest Brasil Ltda., 2003.

BITTAR, Eduardo Carlos Bianca. Direito natural: sentido natural versus cultural. Revista de Informação Legislativa, Brasília, v. 38, n. 152, p. 183-189, out./dez. 2001.

CAMPOS NETO, Antonio Augusto Machado de. A Châr'ia muçulmana. Revista da Faculdade de Direito da Universidade de São Paulo, São Paulo, v. 101, p. 33-70, jan./dez. 2006.

CAMPOS NETO, Antonio Augusto Machado de. A filosofia espírita. O direito natural. O direito justo. Revista da Faculdade de Direito da Universidade de São Paulo, São Paulo, v. 102, p. 617660, jan./dez. 2007.

CAMPOS NETO, Antonio Augusto Machado de. O confucionismo, Budismo, Taoismo e Cristianismo. O Direito chinês. Revista da Faculdade de Direito da Universidade de São Paulo, São Paulo, v. 110, p. 67-94, jan./dez. 2015.

CAMPOS NETO, Antonio Augusto Machado de. O cristianismo ortodoxo. O Direito russo. Revista da Faculdade de Direito da Universidade de São Paulo, São Paulo, v. 109, p. 75-105, jan./dez. 2014.

CAMPOS NETO, Antonio Augusto Machado de. O cristianismo. O direito canônico. Revista da Faculdade de Direito da Universidade de São Paulo, São Paulo, v. 105, p. 39-77, jan./dez. 2010.

CAMPOS NETO, Antonio Augusto Machado de. O hinduísmo. O direito hindu. O direito indiano. Revista da Faculdade de Direito da Universidade de São Paulo, São Paulo, v. 104, p. 71-111, jan./ dez. 2009. 
CAMPOS NETO, Antonio Augusto Machado de. O judaísmo. O direito talmúdico. Revista da Faculdade de Direito da Universidade de São Paulo, São Paulo, v. 103, p. 27-67, jan./dez. 2008.

COÊLHO, Sacha Calmon Navarro. A história da mitologia judaico-cristã: uma teoria sobre as religiões reveladas e servidas por uma antologia comentada de autores seletos. São Paulo: Noeses, 2010.

DAVID, René; JAUFFRET-SPINOSI, Camille. A evolução do direito russo. São Paulo: Editora Dalloz, Jus Navegandi, 1996.

DAVID, René; JAUFFRET-SPINOSI, Camille. Les grands systèmes de droit contemporains. Paris: Dalloz, 1992.

ESSADO, Tiago Cintra (Coord.). Direitos constitucionais e espiritismo. São Paulo: Associação Jurídico-Espírita do Estado de São Paulo, AJE-SP, 2012.

FERREIRA, Aurélio Buarque de Holanda. Novo dicionário da língua portuguesa. Rio de Janeiro: Nova Fronteira, 2016.

GATHIER, Émile. O pensamento hindu. Rio de Janeiro: Agir, 1996.

GILISSEN, John. Introdução histórica ao direito. Tradução de A. M. Hespanha e L. M. Macaísta Malheiros. 2. ed. Lisboa: Fundação Calouste Gulbekian, 1995.

HARADA, Janaína. Idade Média: os mil anos de trevas que definiram os rumos da humanidade. Coleção Mundo Estranho, São Paulo, jun. 2017.

HILL, Jonathan. História do cristianismo. Tradução de Rachel Kopit Cunha, Juliana A. Saad e Marcos Capano. São Paulo: Rosari, 2008.

KAMEL CHAKUR, Abdalla Abdel. O Alcorão Sagrado. São Paulo: Centro Islâmico do Brasil, 1979.

KARDEC, Allan. O livro dos espíritas. São Paulo: Federação Espírita do Estado de São Paulo, 1992.

KAUTSKY, Karl. A origem do cristianismo. Tradução e introdução de Luiz Alberto Moniz Bandeira. Rio de Janeiro: Civilização Brasileira, 2010.

KELSEN, Hans. Teoria pura do direito. 6. ed., 5. tir. São Paulo: Martins Fontes, 2003.

LAGODA, Ekaterina. Instituição jurídica da liberdade de consciência e de religião. Análise comparativa: o estado atual na Rússia, na União Europeia, Itália e Espanha. Revista da Faculdade de Direito da Universidade de São Paulo, São Paulo, v. 106/107, p. 35-47, 2011/2012.

MICHAELIS, Henriette. Dicionário ilustrado: inglês - português/english - portuguese. São Paulo: Melhoramentos, 2010.

POEMA de Gilgamesh: estudio preliminar, traducción y notas de Federico Lara Peinado. Madrid: Tecnos, 1988. (Clásicos del pensamiento). 
QUEIROZ, José Fleurí. Filosofia do direito. A justiça pura e completa. Código de Direito Natural Espírita. São Paulo: Editora e Distribuidora de Livros Mundo Jurídico Ltda., 2006.

SCHMAUS, Michael. Teologia dogmática. Madrid: Editora La Iglesia, 1966. Tomo 3, 4.

TELLES JÚNIOR, Goffredo da Silva. Direito quântico: ensaio sobre o fundamento da ordem jurídica. 8. ed. rev. São Paulo: Juarez de Oliveira, 2006.

TORÁ: a lei de Moisés. Tradução, explicações e comentários do rabino Meir Matzliah Melamed; enriquecida pelos comentários do rabino Menahem Mendel Diesendruck; comentários compilados, redigidos e editados por Jairo Fridlin. São Paulo: Sêfer, 2001.

WILKINSON, Philip. O livro ilustrado das religiões: o fascinante universo das crenças e doutrinas que acompanham o homem através dos tempos. São Paulo: Publifolha, 2000.

XAVIER, Francisco Cândido; PIRES, José Herculano et al. Astronautas do além. São Bernardo do Campo: Grupo Emmanuel, 1983. 